\title{
المقرر لتعليم الكلام في قسم اللغة العربية التابع لكلية الآداب وكلية التربية Mamluatun Ni'mah
}

\section{STAI Zainul Hasan Genggong}

luluknikmahasa@gmail.com

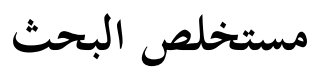

من المحاولة للوصول إلى تعليم مهارة الكلام تعلما فيه للطلاب فلا بد أن تحتاج إلى المقرر، وهو الجزء من البرنامج الدراسي والذي يتضمن مجموعة من الموضوعات الدراسية التي يلتزم الطلاب بدراستها في فترة زمنية محددة قد تتراوح بين فصل دراسي واحد، وعام وندي دراسي كامل وفق خطة محددة. ومقرر التدريس في مهارة الكلام يمدد أنواع المهارات الشفهية التي سوف يتم تدريسها وممارستها خلال التدريس وتنظيم التنفيذ للتعليم والتقييم المنظم بشكل منتظم الذي يشتمل على مكونات مترابطة لتحقيق الإتقان في الكفاءات الأساسية. الكلمات الأساسية: المقرر، مهارة الكلام أساسيات البحث

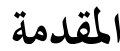

الكلام لغة منطوقة للتعبير عن أفكار ذهنية. واللغة في الأساس هي الكلام، أما

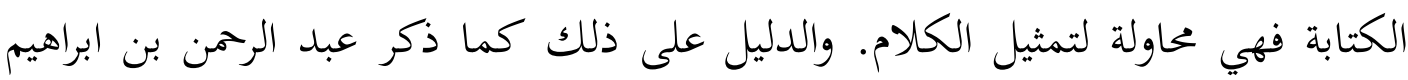

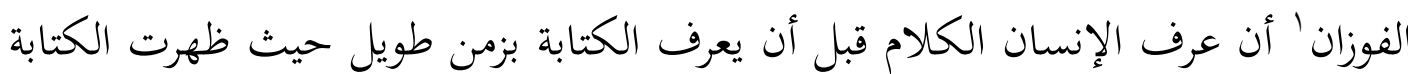
في فترة متأخرة من تاريخ الإنسان، ويتعلم الطفل الكلام قبل أن يأخذ في تعلم الكتابة التي يبدأ في تعلمها عند دخول المدرسة، وجميع الناس الأسوياء يتحدثون بلغاتم الأم بطلاقة، 
ويوجد عدد كبير من الناس لايعرفون الكتابة في لغاقم. وبناء على ما تقدم من أسباب، ينبغي أن نجعل من تعليم الكلام أحد أهم الأهداف في تعليم اللغة العربية لغير الناطقين

إن تعليم اللغة العربية على المستوى الجامعي يعد من أهم مراحل التطور التي مر بها

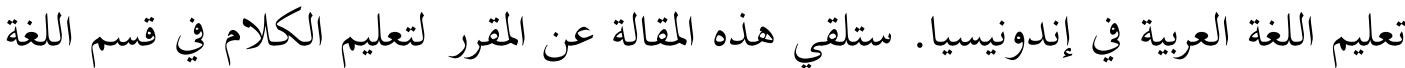
العربية التابع لكلية الآداب وكلية التربية (دراسة تقويمية). فالمقرر هو تحديد بحتيد محتوى التدريس، وهو يرصد ما سوف يتم تدريسه ويجري الإختبار عليه. ومن هنا فإن مقرر التدريس في مهارة الكلام يحدد أنواع المهارات الشفهية التي سوف يتم تدريسها وممارستها

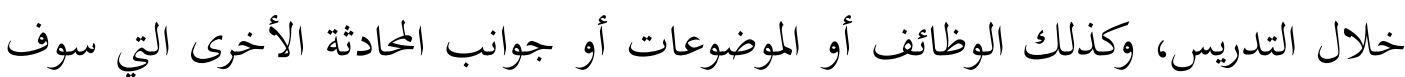
تدرس، والترتيب الذي سوف تظهر عليه في التدريس. وفي هذا البحث أخذت الباحثة نموذج المقرر لتعليم مهارة الكلام في قسم تعليم اللغة العربية كلية التربية وقسم الأدب العربي كلية العلوم الإنسانية والثقافة بجامعة مولنا مالك ابراهيم الإسلامية الحكومية مالانق، وهي

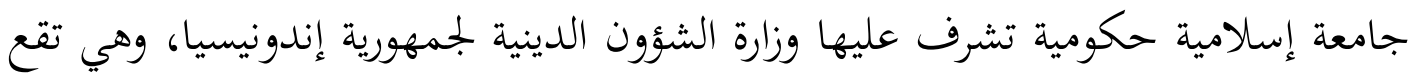
في منطقة مالانق، محافطة جاوى الشرقية.

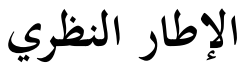

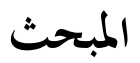

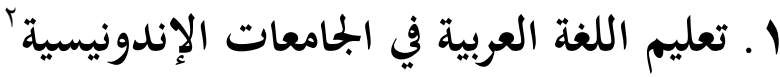

أن تعليم اللغة العربية في الجامعات الإندونيسية يمكن أن نقسمها إلى مرحلتين، وهي تعليم العربية على المنهج القديم، وتعليم العربية بالإتجاهات الجلديدة. ينحصر تعليم اللغة العربية في إندونيسيا في الهدف الديني أي أن المجتمع الإندونيسي يهتم بهذه اللغة بوصفها لغة الدين حيث كان مايستند إليه تعليم هذه اللغة من منهج أو مدخل يمكن وصفه 
تقليديا وهو أنه يركز إلى حد كبير على كوها لغة دينية من دون مراعات كوها لغة أجنبية، مما يسوغ القول: إن تعليمه يتبنى منهجا دينيا أو الإتحاه ديني.

وأهم ما يتمثل فيه هذا الإتجاه الديني بناء المنهج المتبع تعليم اللغة العربية على لـئي الجوانب الداخلية (Internal Focus) من اللغة ولاسيما النحو والصرف والمفردات، حتى إسئ يشتهر هذا المنهج بالمنهج النحوي. وهذا المنهج تأثر من المذهب البنيوي (structuralism) في اللغة حيث ينظر إلى اللغة حسب الجوانب الداخلية فيها من حيث الأصوات والمفردات والقواعد والدلالة، ولايبالي هذا المذهب بشيء خارج اللغة. وإذا طبقنا هذا الفكر اللغوي على مجال تعليم اللغة، فتعليم اللغة إذا تعليم العناصر اللغوية، تعليم الأصوات، تعليم الصرف، تعليم النحو وما إلى ذلك. والمعيار الرئيس في قياس مستوى إجادة اللغة العربية في ضوء هذا المنهج هو القدرة على قراءة النصوص العربية، وبخاصة النصوص الدينية والأدبية، وترجمتها إلى اللغة الإندونيسية. لذا فإن المدف الرئيس من تعليم اللغة العبية وتعليمها وفق هذا المنهج هو الهدف الديني، وهو تعليم اللغة العربية وتعلمها من أجل التمكن من فهم القرآن الكريم، والأحاديث الشريفة وغيرهما من المصادر الدينية الإسلامية.

وفي ضوء هذا الاتحاه الديني والمدخل النحوي كما ذكره نصر الدين إدريس، كان تعليم اللغة العربية على جميع مستوياته يتركز إلى حد كبير على عملية تزويد الطلاب بقواعد اللغة العربية وتدريبهم على الترجمة لكي يتمكنوا من استيعاب النصوص العربية وترجمتها إلى اللغة الإندونيسية .وذلك يتم من خلال توظيف ما يعرف بطريقة النحو والترجمة، تلك الطريقة التي رآها العلماء من أقدم ما يعرف من طرون لإئق تعليم اللغات الأجنبية والتي قد أشارت العديد من الدراسات إلى فشلها وعدم فعاليتها رغم أها لا تزال

rمملوةة الحسنة، واقع تعليم للغة العربية في الجامعات الإندونيسية، مجموعة باحثين في كتاب اللغة العبية في إندونيسيا، (الرياض: دار وجوه

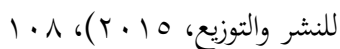

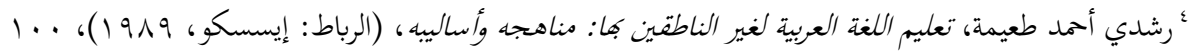

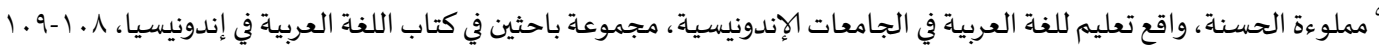


سائدة الاستخدام حتى الآن في مناطق مختلفة من العالم .0 وكان شيوع توظيف هذه الطريقة يعود في المقام الأول إلى أها تتخذ النحو والترجمة وسيلة لتعلم اللغة وتحللها تحليلا

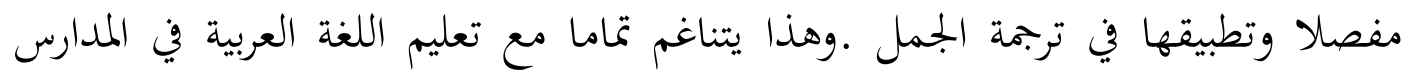

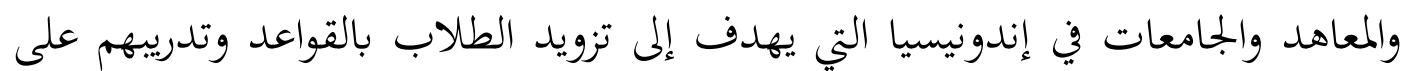
ترجمة النصوص العربية إلى اللغة الإندونيسية أو غيرها من اللغات المحلية ـإضافة إلى ذلك تلك إن هذه الطريقة تسمح استخدام اللغة الوسيطة في عملية التعليم مما يخفف عبء معلمي

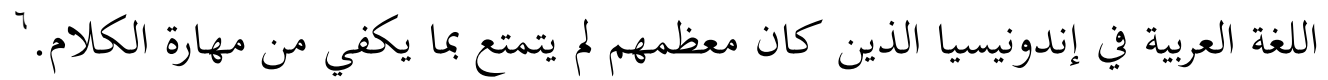

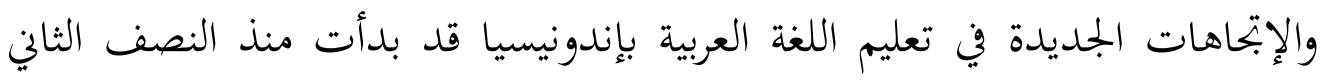
من التسعينيات. ويمكن أن نلاحظها من خلال المنهج التعليمي والإدارة التعليمية والموارد البشرية، إذ إن منهج تعليم اللغة العربية في ضوء هذه الإتجاه الجديد يتسم بأنه لاينحصر

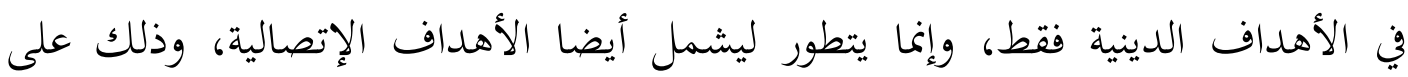

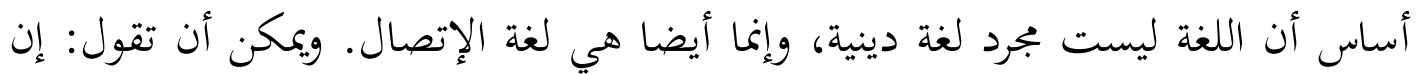
المنهج الجميد لاينحصر في الجوانب الداخلية من اللغة وإنما يهتم كذلك بالجوانب الخارجية من اللغة. وهذا النوع جديد من المنهج الدراسي في الحقيقة هو استجابة (external focus) لتطور المذهب اللغوي من البنيوي إلى الوظيفي حيث قال: إن أهمية اللغة هي وظيفتها لا

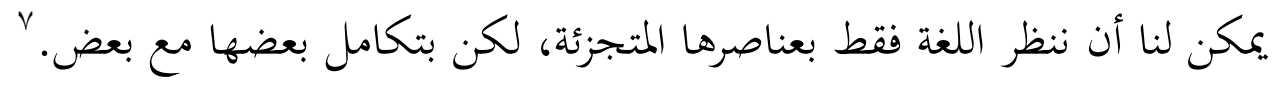
أولا: تقسيم تعليم اللغة العربية في الجامعات الجامعات رمز التقدم والحضاري، لذلك فقد عني بتأسيسها حكومة إندونيسيا

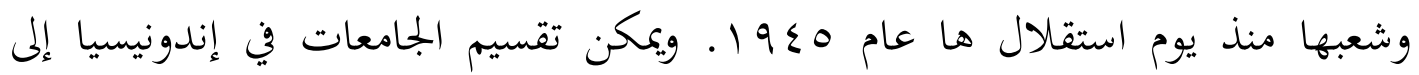

لنصر الدين ادريس جوهر، التحاهات جديادة في مجال تعليم اللغة العربية في إندونيسيا، Journal Of Indonesian Islam Vol.01 Number 01

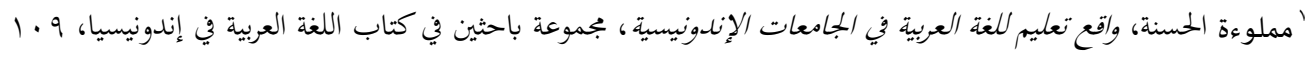


قسمين: جامعات تابعة لوزارة التربية والثقافة، وجامعات تابعة لوزارة الشؤون الدينية. أما

$$
\text { تعليم اللغة العربية في الجامعات فيمكن تقسيمه إلى أربعة أنواع:^ }
$$

أ. تعليم اللغة العربية في قسم اللغة العربية وآدابها، وقد يطلق عليه اسم قسم الأدب العربي. يوجد هذا القسم في الجامعات العامة أو في الجامعات الدينية الإسلامية. يهدف هذا

القسم إلى تخريج الخبراء والباحثين المتخصصين في علوم اللغة العربية وآدابها وثقافتها. ب.تعليمها في قسم تعليم اللغة العبية الذي يهدف إلى تخريج معلمي اللغة العربية في المدارس العامة والإسلامية، في جميع المستويات التعليمية. ت. تعليم اللغة العربية في كلية العلوم الإسلامية وأقسامها، نذكر منها على سبيل المثال لا الحصر: قسم التفسير، وقسم الحديث، وقسم العقيدة والفلسفة في كلية أصول الدين، وقسم التربية الدينية في كلية التربية، وقسم الإعلام الإسلامي في كلية الدعوة، وقسم القضاء في كلية الشريعة وغير ذلك. فتعليم اللغة العربية في هذا الأقسام يهدف إلى تزويد الطلبة بالكفاءة اللغوية العربية وفق مايحتاج إليه تخصصهم في العلوم الأسلامية. ث. تعليمها في أقسام كليات أخرى، مقسم الأدب الاندونيسي في كلية الأدب ، وقسم البنك الشرعي في كلية الإقتصاد، وقسم العلاقات الخارجية في كلية العلوم الإجتماعية والسياسية وغيرها. ويهدف تعليم اللغة العربية فيها إلى تزويد الطلبة بالكفاءة اللغوية العربية وفق مايكتاج إليه تخصصهم أو مهنتهم في المستقبل.

\section{ثانيا: المناهج الدراسية لتحقيق الكفايات المرجوة من خريبي تعليم اللغة العربية} كان الهدف الأساسي من قسم تعليم اللغة العربية العامة هو تأهيل معلمي اللغة العربية. فلذا يجب أن يكون لدى خريجي أقسام اللغة العربية الشروط الأساسية لأهلية المعلم وهي: الأول، توافر الكفاية اللغوية. واثثاني، متانة المادة اللغوية والإلمام بها. والثالث، الإلمام بقواعد التدريس. أو بقول آخر: إن هناك ثلاث كفايات لمعلم اللغة، وهي الكفاية

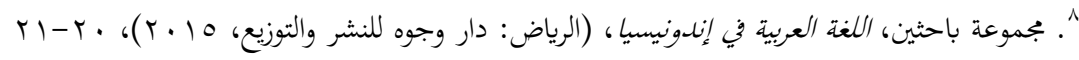
" اقرأ هذه الشروط في نظام الحكومة الإندونيسية عن المعلم والمحاضر. وهذه الشروط مناسبة لما قدمه عبد المجيد عيساني، نظريات التعلم

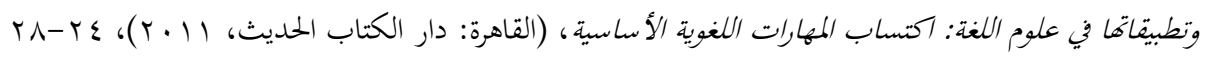


المعرفية، الكفاية المهنية، الكفاية المنهجية. إضافة إلى ذلك فإن هناك كفاية لا تقل أهميتها في تكوين المعلم الجيد وهي الكفاية الشخصية. وهذا الرسم البياني عن المواد الدراسية الموجودة في المناهج الدراسية في قسم تعليم اللغة العربية ومدى تحقيقها للشروط والكفايات

\begin{tabular}{|c|c|c|c|}
\hline المواد الدراسية & الكفاية المرجوة & الأساسية لأهلية & النمرة \\
\hline 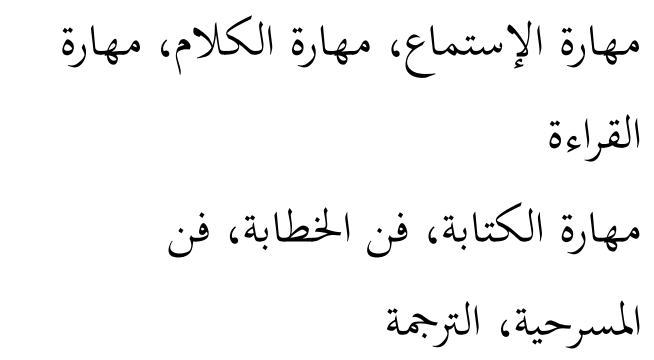 & (الجانباية الإتصالية & التوافر الكفاية & 1 \\
\hline 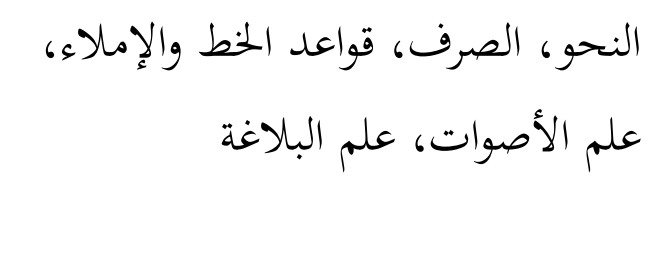 & والكفاية المعرفية & متانة المادة & r \\
\hline 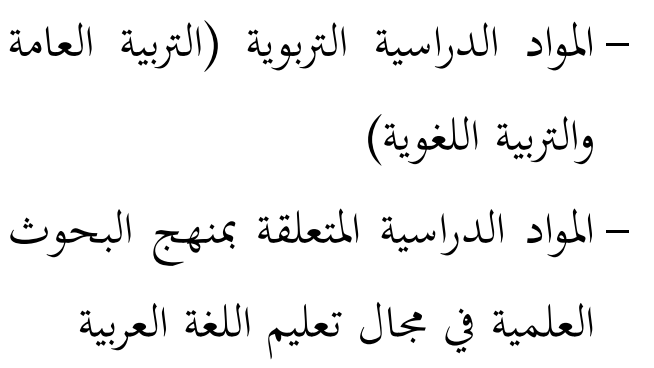 & الكففاية المهنية & التدريس & r \\
\hline $\begin{aligned} \text { المواد الدراسية لتطوير الشخصية } \\
\text { الإسلامية والإندونيسية }\end{aligned}$ & الكفاية الشخصية & الشختازة & $\varepsilon$ \\
\hline
\end{tabular}

ثالثا: المناهج الدراسية لتحقيق الكفايات المرجوة من خويجي قسم اللغة العربية وآدابما 
إن الأهداف المرجوة من خريجي هذا القسم فيما يلي:"

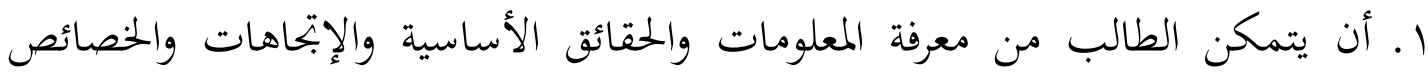
والمذاهب، وأن يكون قادرا على اكتساب هذه المعارف والحقائق والوقوق على هذه

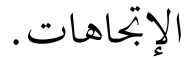

r. أن يتكون لديه الإهتمام بدراسة هذا الحقل من التخصص، وتنمو عنده الرغبة في متابعة هذه الدراسة والتعمق فيها، وأن يتذوق الإنتاج الأدبي واللغوي ويقدر الجهود التي بذها العلماء والأدباء في هذا المجال. r. أن يصبح قادرا على تقويم الآراء والمذاهب والأفكار في هذا الحقل من التخصص، وأن ينقدها ويبين قيمتها العلمية أو الأدبية على أصولها وعواملها. ـ. أن يقف على العلاقة المتبادلة بين الحركات العلمية في حقل تخصصه في العصور المختلفة وعلاقتها بالعوامل الإجتماعية والسياسية بعامة من جهة أخرى. ه. أن يتعرف على أمهات الكتب والمراجع والأعمال العلمية البارزة وما أضافته إلى حركة التقدم العلمي في مجال هذا الحقل. 7. أن تمكنه دراسته من الوقوف على أساليب البحث العلمي ومناهجه وأدواته في هذا الحقل وعلى تحليل النتائج وتقويمها. V. أن يصبح قادرا على إجراء البحث العلمي في حقل تخصصه، بما في ذلك قدرته على تحديد موضوع البحث واختياره المنهج العلمي لدراسته.

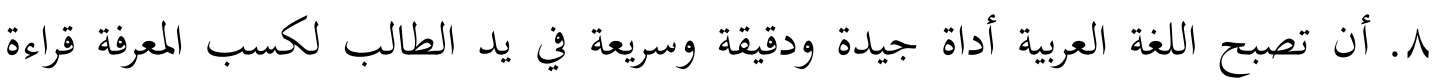
وسماعا للتعبير عها شفويا وكتابيا. 9. أن تكشف دراسته اللغة العربية عما يكون لدى الطلا من قدرات لغوية وميول أدبية وأن تساعده في تنميتها. 
• 1.أن تخرج الكوادر اللازمة من المتخصصين في هذه اللغة لسد احتياجات المجتمع من

هذه التخصص.

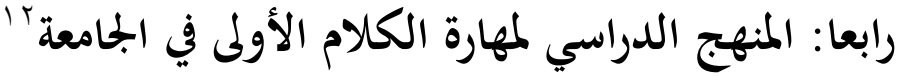

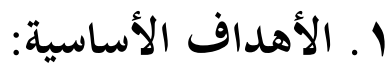

أ. تحقيق الكفاية اللغوية: معرفة النظام الذي يهكم به اللغة، ويطبق من دون إنتباه أو الأوالئا

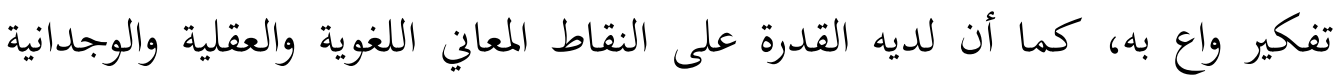
والثقافية التي تصحب الأشكال اللغوية المختلفة. ب.تحقيق الكفاية الإتصالية في اللغة العربية وهي قدرة الفرد على استعمال اللغة بشكل

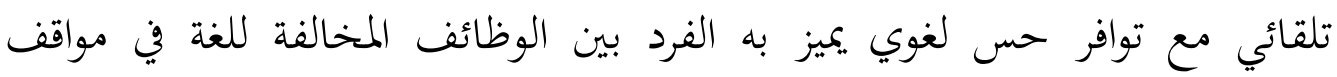
الإستعمال الفعلي.

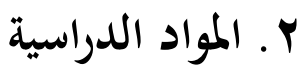

أ. المكونات لتحقيق الإتصال: دور الفرد في المجتمع، دور الفرد في الأداء اللغوي، غاية

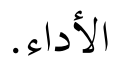

$$
\text { ب.غاية الأداء اللغوي: التعامل والإفصاح الخبر والإنشاء }
$$

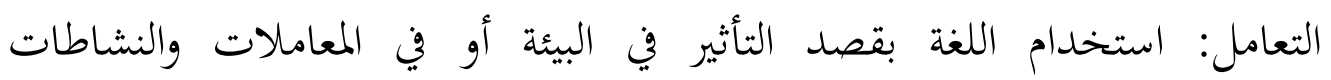
الاجتماعية المخيطة بالفرد، فيدخل في ذلك البيع والشراء والمخاصمة، والتعليم والبحث العلمي والمناقشات الموصلة إلى قرارات والتأليف والخطابة, والمقالة،

$$
\text { والسياسة، والتعليق الإذاعي، ونشرة الأخبار وهلم جرا. }
$$

الإفصاح: استعمال اللغة بقصد التعبير عن موقف نفسي ذاتي دون إرادة التأثير في

$$
\text { البيئة. }
$$

ت.العيارات العربية حسب الغايات والمقامات، مثل عبارات غايتها الخطاب العادي وبعض عناصر المقام الأخرى، عبارات غايتها الوداع وبعض عناصر المقام الأخرى

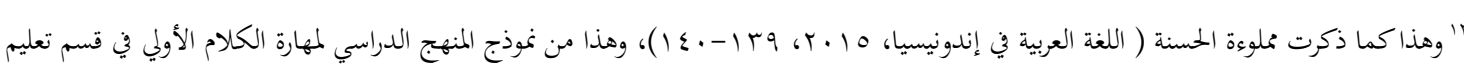

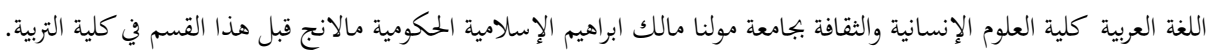


ويمكن فيها، عبارات غايتها الإستقبال وبعض عناصر المقام الأخرى ويمكن فيها، عبارات غايتها الالتزام وبعض عناصر المقام الأخرى ويمكن فيها، والعبارات الأخرى.

أ. الإختبار لمعرفة الكفاية في الأداء الإفصاحي

ب. الإختبار لمعرفة الكفاية في الأداء التعاملي

r. تعليم مهارة الكلام

أولا: مفهوم مهارة الكلام مهام المام

يعني مفهوم الكلام في اصل اللغة هو عبارة عن الأصوات المفيدة، وعند المتكلمين المعنى القائم بالنفس الذي يعبر عنه بألفاظ، يقال في نفسي كلام، وفي اصطلاح النحاة

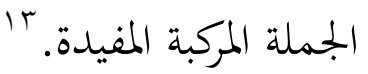

أما التعريف الاصطلاحي للكلام فهو ما يصدر عن الإنسان من صوت يعبر به عن شيء له دلالة في ذهن المتكلم والسامع، أو على الأقل في ذهن المتكلم. ؟ أل ثانيا: أسس تعليم مهارة الكلام

ومن الأسس من تعليم مهارة الكلام هي الأسس النفسية، والأسس التربوية، والأسس مهس

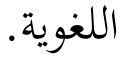

ومن الأسس النفسية هي: (1) الإنسان بطبيعته ميال إلى التحدث عن نفسه

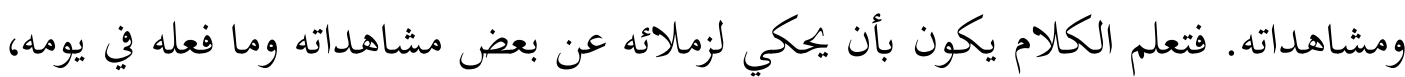
(r) أن يكون الحديث استجابة لدافع نفسي يصدر من المتكلم ويجعله ينطلق في حديث هو تتركز الحوافز والدوافع النفسية حول التعبير عن مواقف الحياة، وما تستدعيه هذه المواقف من حديث حول مطالب الأسرة ومطالب الحياة اليومية من البائعين والموظفين وغيرهم، (r) غلبة الخجل والتهيب عند بعض المتكلمين بتشجيع الأفراد الخجولين وإغرائهم بالكلام، وأخذهم باللين والصبر، وإيجاد الدافع للكلام، (ع) الإنسان بطبيعته 
يرغب في المحاكاة والتقليد بغيره. فيطلب من المتكلم أن يقلد أستاذا أو إنسانا آخر أعجبه ويجب تقليده، (0) يجب أن تكون موضوعات الكلام داخله في خبرة المتكلمين وليست بعيدة عن ثروقم اللغوية

ومن الأسس التربوية هي (1) حرية المتكلم في عرض الأفكار التي يريد التعبير عنها،

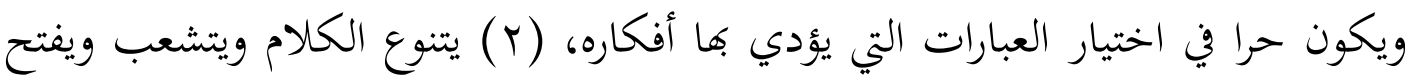

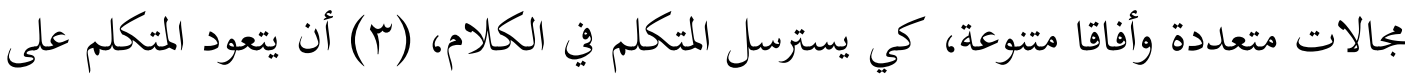

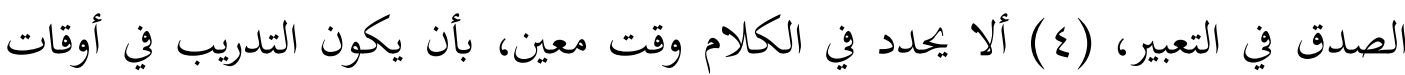
خختلفة ومن خلال مواقف متعددة، (0) أن تختار موضوعات الكلام من مجال خبرات المتكلمين مثل الحديث عن المجتمع وما فيه من تفاعل وأحداث.

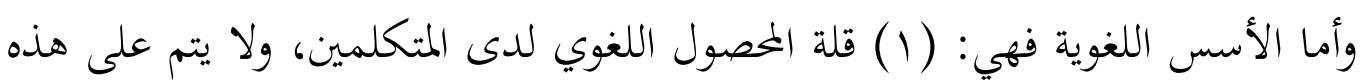

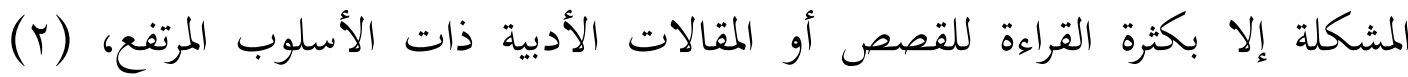

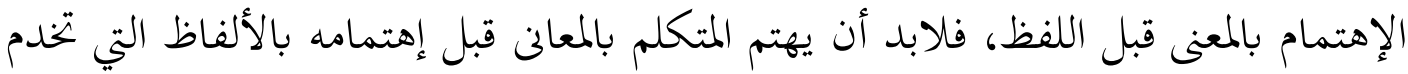

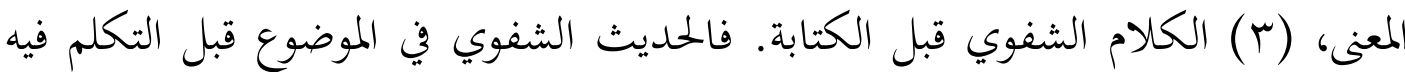

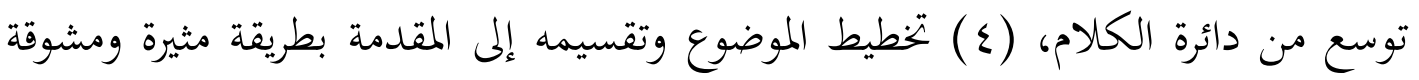
بحذب انتباه السامع والعرض بطريقة سليمة والخاتمة بطريقة جيدة. (ه) اختيار الكلمات والجمل والتعبيرات اللازمة لكل فكرة بحيث تتضف بسلامة التركيب والموضوع والاكتمال وصحة استخدام أدوات الربط بحسب المعنى. ثالثا: أهداف تعليم الكلام

يهدف تعليم الكلام عند محمود كامل الناقة إلى تحقيق مايلي:

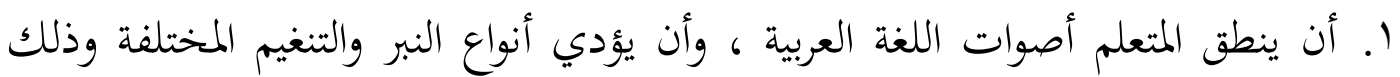
بطريقة مقبولة من أبناء العربية. r. أن ينطق أصوات المتجاورة والمتشاهة.

" محمود كامل الناقة، تعليم اللغة العربية للناطقين بلغات أخرى: أسسه-مداخله-طرق تدرليسه، (مكة المكرمة: جامعة أم القرى، بدون سنة)، . با-ب 
r. أن يدرك الفرق في النطق بين الحركات الطويلة والقصيرة.

ـ. أن يعبر عن أفكاره مستخدما الصيغ النحوية المناسبة.

ه. أن يعبرعن أفكاره مستخدما للنظام الصحيح لتركيب الكلمة في العربية خاصة في لغة

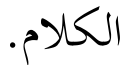

T. أن يستخدم بعض خصائص اللغة في التغبير الشفوي مثل التذكير والتأنيث وتمييز العدد والحال ونظام الفعل وأزمنته وغير ذلك منما يلزم المتكلم بالعربية.

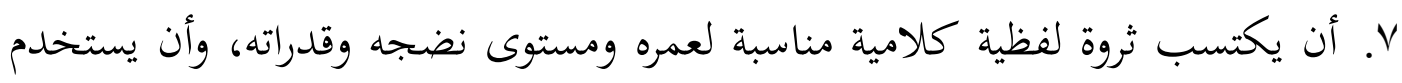
هذه الثروة في إتمام عمليات اتصال عصرية.

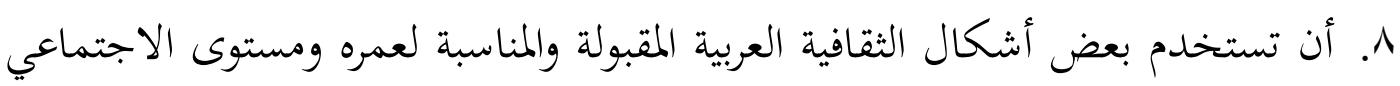
وطبيعة عمله، وأن يكتسب بعض المعلومات الأساس عن التراث العربي والأسلامي. 9. أن يعبر عن نفسه تعبيرا واضحا ومفهوما في مواقف الحديث البسيطة.

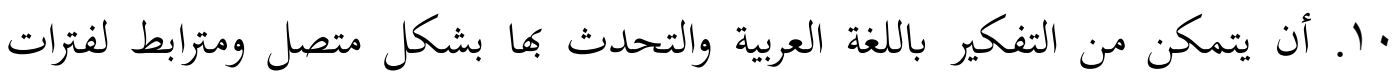
زمنية مقبولة.

\section{رابعا: توجهات عامة لتدريس الكلام}

كانت بجموعة من التوجيهات العامة التي قد تسهم في تطوير تدريس مهارة الكلام

في اللغة العربية كلغة ثانية عند محمود كامل الناقة ورشدي أحمد طعيمة، وهي: 1- تدريس الكلام يعني ممارسة الكلام : يقصد بذلك أن يتعرف الطالب بالفعل إلى

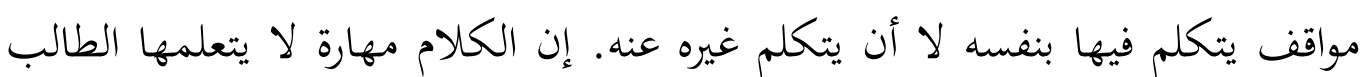
إن تكلم المعلم وظل هو هستمعا. من هنا تقاس كفاءة المعلم في حصة الكام بمام بمقدار صمتة وقدرته على توجيه الحديث وليس بكثرة كلامه واستئثاره بالحديث. r- أن يعبر الطلاب عن خبرة : يقصد يذلك ألا يكلف الطلاب بالكلام عن شيئ ليس

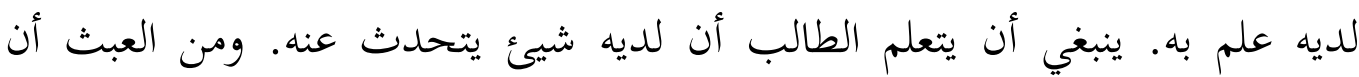


يكلف الطالب بالكلام في موضوع غير مألوف إذ أن هذا يعطل فهمه. وقد لا يحد في رصيده اللغوي ما يسعفه.

rـ التدريب على توجيه الانتباه : ليس الكلام نشاطا آليا يردد فيهالطالب عبارات معينة وقتما يراد منه الكلام. إن الكلام نشاط عقلي مركب. إنه يستلزم القدرة على تمييز الأصوات عند سماعها وعند نطقها. والقدرة على تعرف التراكيب وكيف أن إختلافها يؤدي إلى اختلاف المعنى. إن الكلام باختصار نشاظ ذهني يتطلب من الفرد أن يكون

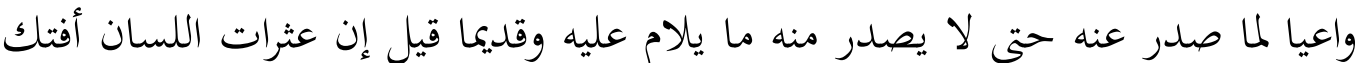

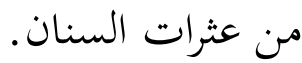
عـ عدم المقاطعة وكثرة التصحيح : من أكثر الأشياء حرجا للمتحدث وإحباطا له أن

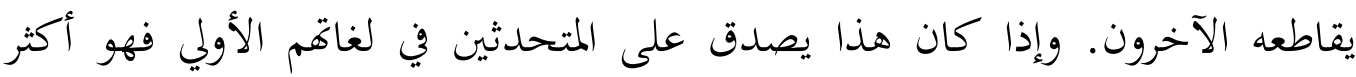

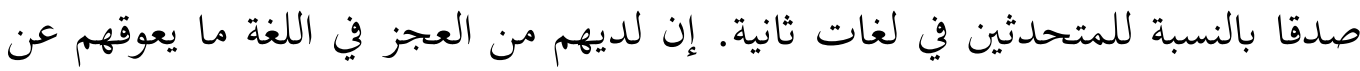

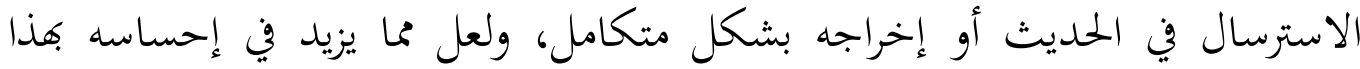
العجز أن يقاطعه المعلم. ويرتبط بهذا أيضا ألا يُلح المعلم في تصحيح أخطاء الطلاب. هـ مستوى التوقعات : من المعلمين من تزيد توقعاته كما سبق القول عن الامكانات

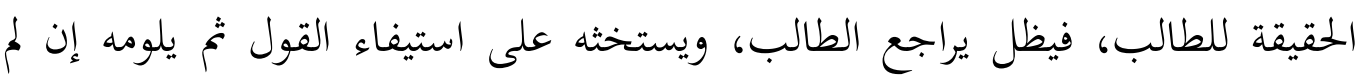
يكن عند مستوى التوقعات. إن الحقيقة التي ينبغي أن يعرفها معلم العربية كلغة ثانية

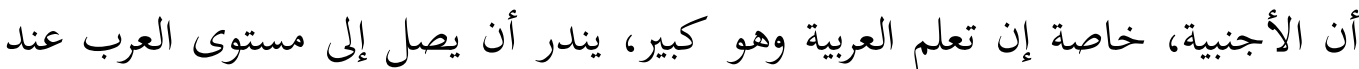

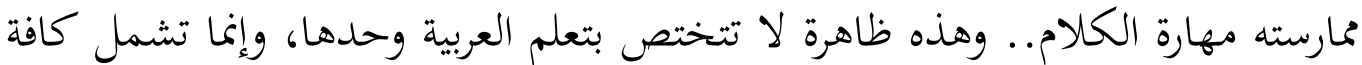
الدارسين للغات الثانية. وعلى المعلم إذن أن يقدّر ذلك،وأن يكون واقعيا. وأن يميز بين الثين مستوى الكلام الذي يصدر عن الناطقين بالعربية وذلك الذي يصدر عن الناطقين

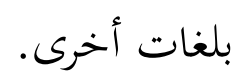
דـ التدرج : ينطق مبدأ التدرج هنا أيضا.. إن الكلام، كما قلنا، مهارة مركبة ونشاط

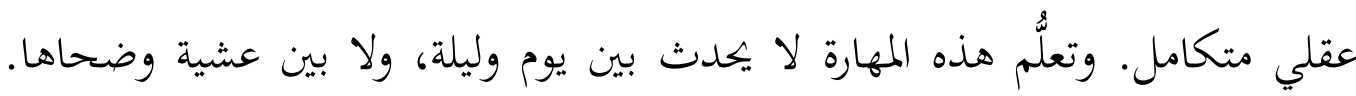


إذا عملية تستغرق وقتا وتتطلب من الصبر والجهاد والحكمة ما ينبغي أن يملكه المعلم. وعليه أن يهيئ من مواقف الكلام ما يناسب مع كل مستويات الدارسين. خامسا: مراحل التدريب على الكلام

يمكن التدريب على مهارة الكلام من خلال أساليب متعددة كل منها يناسب مرحلة

تعليمية مختلفة، وهي:

$$
\text { أ. المرحلة الأولى: حوارات مغلقة الإحابة وفيلة }
$$

مرحلة مبتدئة من مراحل التدريب على الكلام يغلب عليها طابع ترديد القوالب مع الِّابل

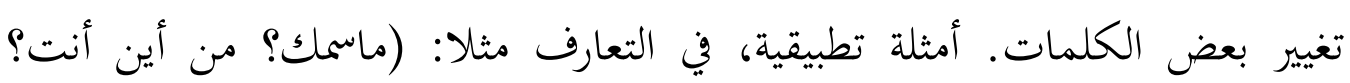

$$
\left(\lambda^{\prime} \cdots . . .\right.
$$

ب. المرحلة الثانية: حوارات مفتوحة الإجابة

وهي مرحلة تختلف عن المرحلة الأولى بزيادة المتطلبات الفكرية واللغوية للحوار. مثل:

$$
\text { ت. المرحلة الثالثة: التعبير الموجه أو المقيد، التعبير عن أفكار قصيت إلى السوق؟ ماذا اشتريت؟....الخا) }
$$

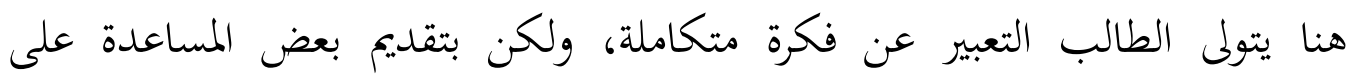
مستوى الأفكار أو اللغة أو كليهما. مثل: (عرض صورة لوصفها، أو عرض سلسلة من الصور لنكوين قصة، أو وصف تفصيلي لمحتويات صور متفرقة، أو التلخيص)

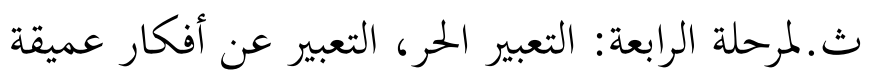

وهي مرحلة تناسب المستويات المتقدمة من تعلم اللغة، يقوم فيها الطالب بتقديم

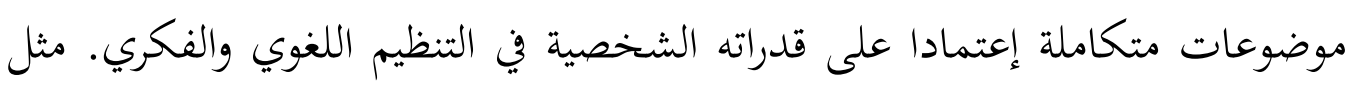
ذلك:

- تناول مشكلة بالتحليل (مثل: كيف ينهض العالم الاسلامي؟) 
- المقارنة بين شيئين والوصول إلى أفضلية أحدهما على الآخر (مثل: أيهما أكثر فائدة في بناء الحضارة الصناعة أو الزراعة؟ )

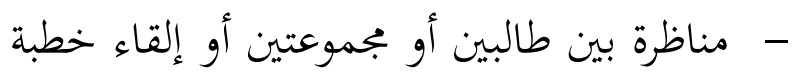

\section{سادسا: اختبارات مهارة الكلام}

يهدف اختبار الكلام إلى قياس القدرة على الكلام بالمستويات مختلفة. ومن وسائل ياس القدرة الكلامية، وهي: القراءة الجهرية، والإعادة الشفهية والتحويل، المحاورة، المقابلة

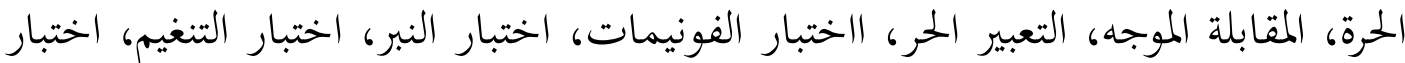

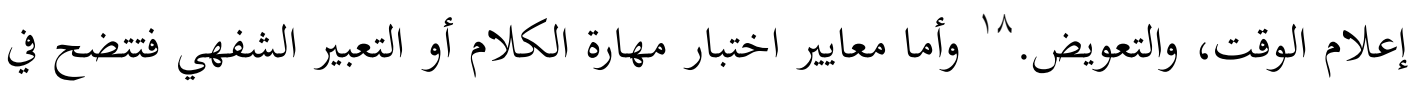

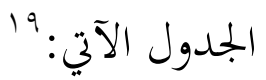

معايير تقويم مهارة الكلام

\begin{tabular}{|c|c|}
\hline النتيجة & النطق \\
\hline 。 & يخالطه أثر قليل من اللكنة الأجنبية \\
\hline$\varepsilon$ & مفهوم بوضوح، ولكن هناك لكنة أجنبية واضحة \\
\hline r & مشكلات نطقية تستدعي استماعا مركزا، وأحيانا تؤدي إلى سوء فهم \\
\hline r & باستمرار بعب فهمه بسبب مشكلات نطقية. يطلب منه إعادة مايقوله \\
\hline 1 & لديه مشكلات نطقية عضوية تجعل حديثه غير مفهوم تماما \\
\hline النتيجة & القواعد \\
\hline 。 & أخطاء القواعد وترتيب الكلمات قليلة لا تذكر \\
\hline$\varepsilon$ & يقع أحيانا في أخطاء نحوية لكنها لا تسبب غموا في المعنى \\
\hline r & من حين لآخر يقع في أخطاء نوية تسبب غموا في المعنى \\
\hline
\end{tabular}

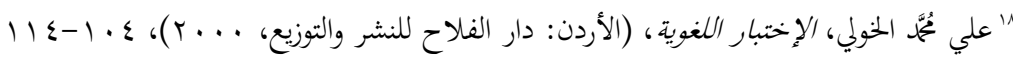

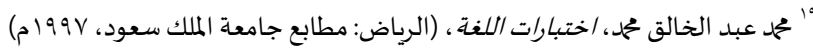




\begin{tabular}{|c|c|}
\hline r & بقيد نفسه باستعماء القواعد بتعل الفهم مستعصيا منا يجعله يعيد صياغة جملة و / أو \\
\hline 1 & أخطاؤه النحوية كثيرة إلى درجة تجعل حديثه غير مفهوم تماما \\
\hline النتيجة & 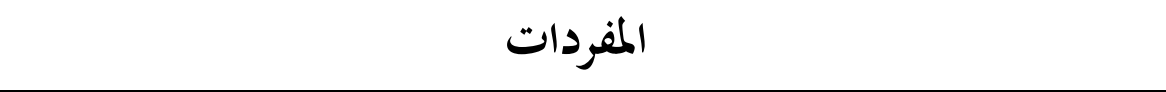 \\
\hline 0 & يستعمل المفردات والعبارات الاصطلاحية كمحدثي اللغة تماما \\
\hline$\varepsilon$ & صيتعمل المصطلحات غير صحيحة أحيانا و / أو يجد نفسه بجبرا لإعادة \\
\hline r & 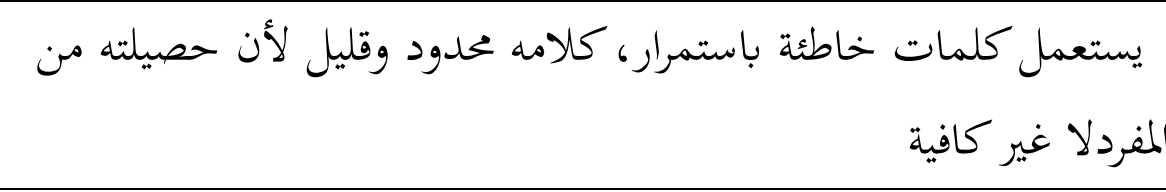 \\
\hline r & فهمده استعماله الخاطئ للكلمات وقلة حصيلته من المفردات بتعل من الصعب \\
\hline 1 & محدودية ما عمده من مفردات تجعله غير قادر على الحديث تماما \\
\hline النتيجة & الطلاقة \\
\hline 0 & طلق اللسان مثله مثل متحدث اللغة الأصلي ع \\
\hline$\varepsilon$ & سرعة الحديث تبدو أهما تتأثر تأثرا طفيفا بمشكلات لغوية \\
\hline$r$ & السرعة والطلاقة متأثرتان بشدة بمشكلات لغوية \\
\hline r & دائم التردد، يجد نفسه مجبرا للسكوت بسبب محدودية اللغة \\
\hline 1 & الحديث متعثر ومتقطع بحيث يجعل المحادثة مستحيلة \\
\hline النتيجة & الفهم \\
\hline 0 & يبدو أنه يفهم كل شيء دون صعوبة \\
\hline$\varepsilon$ & يفال لهم كل شيء يقال بالسرعة العادية تقريبا، إلا أنه لا بد من إعادة ما \\
\hline$r$ & يفهم معظم ما يقال له إذا كان بسرعة أبطأ من سرعة الحديث العادي \\
\hline
\end{tabular}




\begin{tabular}{|c|c|}
\hline & مع التكرار \\
\hline r & إذا ما كاند صعوبة كبيرة في متابعة ما يقال، يستطيع فهم (المحادثات الإجتماعية) \\
\hline 1 & لا يمكن أي يقال بأنه يفهم حتى أسهل المحادثات وأبسطها \\
\hline
\end{tabular}

هناك تعريفات كثيرة للمقرر الدراسي الذي يقدمها خبراء التعليم. منها كما ذكر مولياسا ان المقرر الدراسي هو خطط التعليم في مجموعة الدراسة بالموضوعات المحددة التي تشمل معايير الكفاءة والكفاءات الأساسية والمواد التعليمية والمؤشرات والتقييمات ومخصصات الوقت والمصادر التعليمية التي طورتا كا وحدة تعليمية. ‘r يعني المقرر الدراسي هو الجزء من البرنامج الدراسي والذي يتضمن بجموعة من الموضوعات الدراسية التي يلتزم الطلاب بدراستها في فترة زمنية محددة قد تتراوح بين فصل دراسي واحد، وعام دراسي كامل وفق خطة محددة. ويرتبط المقرر الدراسي بمفهوم الخطة الدراسي (Syllabus)، تلك التي تشير إلى توصيف كامل للمقرر الدراسي الذي يدرسه الطلاب من حيث تحديد القائم على تدريسه، والفئة الطلابية المستهدفة، وبجموعة الأهداف التعليمية المراد تحقيقها من خلاله والموضوعات التي يتناولها المقرر، وتوزيعها على مدة الدراسة وأهم المتطلبات التعليمية اللازمة لتنفيذه، وأساليب التقويم التي تستهدف الحكم على مدىى تحقق أهدافه، وقائمة المراجع التي

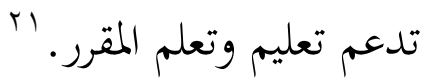

20 E Mulyasa, Kurikulum Tingkat Satuan Pendidikan: Suatu Panduan Praktis (Bandung: Remaja Rosdakarya, 2007) 15

$$
\text { "محمد السيد على، مصطلحات في المناهج وطرق التدري، (المنصورة عامر للطباعة والنشر، 1911)، 1) }
$$


وذكرت إيلا ان المقرر الدراسي هو مجموعة من الخطط وتنظيم التنفيذ للتعليم والتقييم المنظم بشكل منتظم الذي يشتمل على مكونات مترابطة لتحقيق الإتقان في

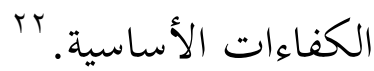

ومن هنا فإن مقرر التدريس في مهارة الكلام يحدد أنواع المهارات الشفهية التي سوف يتم تدريسها وممارستها خلال التدريس، وكذلك الوظائف أو الموضوعات أو تهرئ جوانب المحادثة الأخرى التي سوف تدرس، والترتيب الذي سوف تظهر عليه في

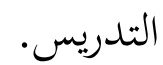
ثانيا: مكونات وإعداد المقرر الدراسي أما مكونات المقرر الدراسي فهي (1) المادة الدراسية، (ץ) الشفرة، (ب) المستوى، المكي، (ع) وحدة إئتمان الفصل الدراسي SKS، (ه (ه) الكلية أو القسم، (ج) المادة المشروطة،

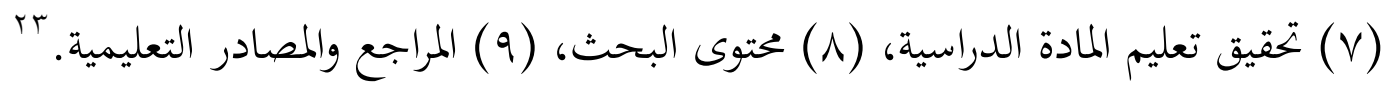
ثالثا: اختيار إطار المقرر

يصف المقرر العناصر الرئيسة التي سوف تستخدم في تخطيط الدراسة، ويقدم الأساس لما سوف يتم التركيز عليه من مواد تدريسية ومحتوى معين. سوف نستعرض الآن طبيعة هذه

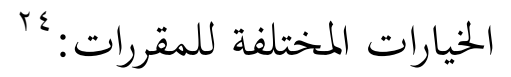

\section{ا. المقرر القواعدي أو البنائي Grammatical or structural syllabus}

وهو المقرر المنظم حول العناصر القواعدية ـ وقد تم استخدام المقررات القواعدية تقليديا لتشكل أساسا لتخطيط الدورات العامة، خاصة للمتعلمين في المستوى المبتدئ .إن اختيار العناصر القواعدية في مقرر للقواعد وتحديد تتابعها لايعكس السهولة أو الصعوبة الداخلية

22 Ella Yulaelawati, Kurikulum dan Pembelajaran: Filosofi Teori dan Aplikasi, (Bandung: Pakar Raya, 2004), 123

23 Erfan Soebahar, "Membuat Silabus dan rencana Pembelajaran Semester-Prof. DR. H.M.Erfan Soebahar," accessed Okober 16, 2018, http://erfansoebahar.web.id/membuat-silabus-dan-rencanapembelajaran-semester/.

گ' جاك ريتشاردز، تطوير مناهج تعليم اللغة العربية Curriculum Development in Language Teaching، ترجمة ناصر بن عبد الله

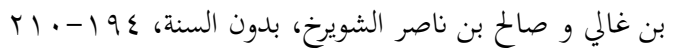


للعناصر فحسب، ولكنه يعكس أيضا علاقتها مع الجوانب الأخرى في المقرر والتي قد يتم

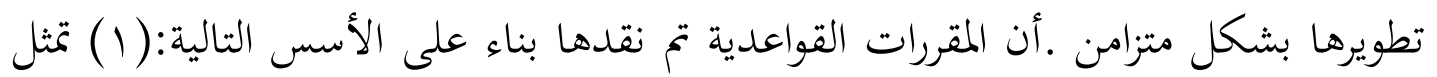

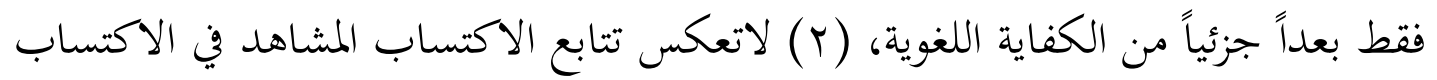
الطبيعي للغة الثانية، (r) تركز على الجملة لا على الوحدات الأطول في الخطاب، (ع) تركز على الصيغة لا المعنى (0) لا تعابج المهارات الاتصالية.

lexical syllabus المقرر الدلالي:

وهو مقرر يحدد المفردات الهدف التي يجب تدريسها، وتكون مرتبة عادة وفقا للمستويات مثل . . ه أو . . . أو . . . . ب كلمة الأولى . وقد رأينا أن مقررات المفردات كانت من بين الأنواع الأولى من المقررات التي تم تطويرها في تدريس اللغة. ونظرًا لأن

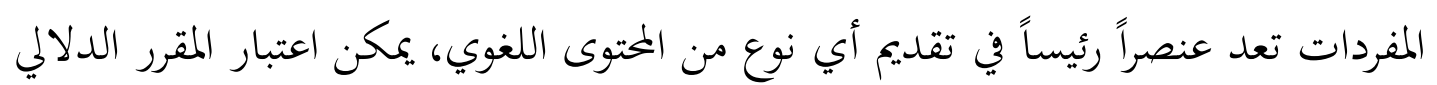
مجرد أحد الجوانب في مقرر أكثر شثمولية. واليوم هناك درجة كبيرة من الاتفاق في تدريس اللغة الإنجليزية فيما يتعلق بأهداف تدريس المفردات في المستويات المختلفة، ويميل مؤلفو الكتب الدراسية والمواد التعليمية إلى المحافظة على المواد التعليمية ضمن نطاق المفردات الهدف .والمفردات الهدف لدورة في الإنجليزية العامة هي:

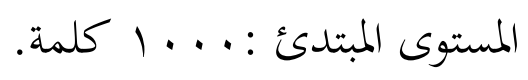
المستوى المتوسط : . . . ب كلمة إضافية. المستوى فوق المتوسط : . . . ب كلمة إضافية. المستوى المتقدم : . . . ب + كلمات إضافية ) .

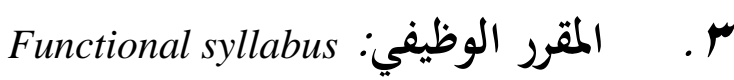

وهو المقرر المنظم حول الوظائف الاتصالية مثل الطلب والشكوى والاقترح والاتغاق

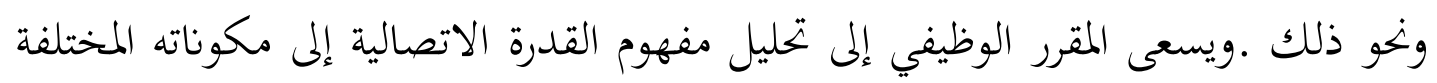
من منطلق أن إتقان الوظائف الفردية سوف يؤدي إلى القدرة الاتصالية العامة .وقد تم 
اقتراح المقررات الوظيفية في البداية في سبعينات القرن العشرين الميلادي بوصفها جزءًا من حركة تدريس اللغة الاتصالي، وقد شكلت الأساس لكثير من الدورات اللغوية والكتب الدراسية منذ ذلك الوقت .وتعد أحد المقترحات الأولية للمقرر الاتصالي، أي ذلك الذي مئي يعالج القدرة الاتصالية لا القدرة اللغوية linguistic competence. وقد تم تحديد الوظائف

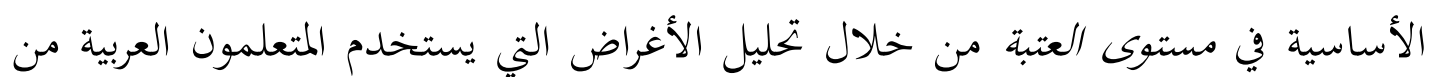

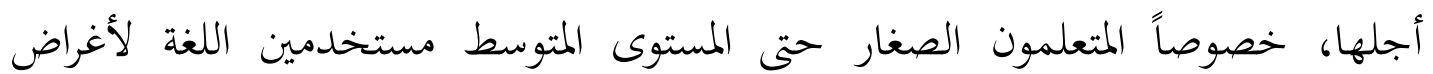
الكفاف الاجتماعي والسفر، وقد نتج عن هذا مقرر وظيفي تم استخدامه على نحو واسع،

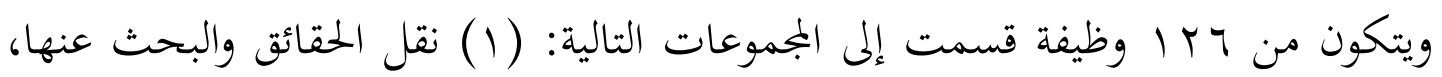

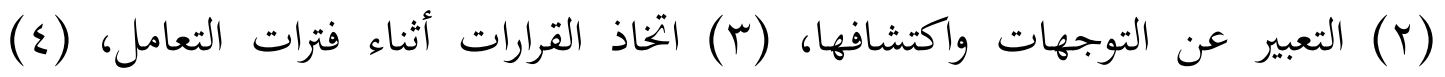
التكيف الاجتماعي socializing، (0) بناء الخطاب، (7) إصلاح الاتصال . وقد أثبتت المقررات الوظيفية شعبيتها لتشكل أساسا لتنظيم الدورات والمواد التعليمية لألسباب التالية: - ne ا ـ تعكس نظرة أكثر شمولية للغة من نظرة المقررات القواعدية، وتركز على استخدام اللغة لا على الصيغة اللغوية. r. يمكن ربطها بسهولة بالأنواع الأخرى من محتوى المقرر (مثل الموضوعات والقواعد والمفردات) r. تقدم إطارا ملائما لتصميم المواد التدريسية خاصة في مجالي الاستماع والكلام . عituational syllabus : المقرر الموقفي وهو المقرر المنظم حول اللغة المستخدمة في مواقف مختلفة مثل المطار أو الفندق . والموقف هو عبارة عن محيط تحدث فيه عادة أحداث اتصالية معينة. ويحدد المقرر الموقفي موري المواقف التي سوف يستخدم فيها المتعلم اللغة والأحداث الاتصالية العادية واللغة المستخدمة في ذلك المحيط ـوقد كانت المقررات الموقفية خاصية مألوفة لكتب تدريس اللغة منذ قرون 
وهي تستخدم غالبا في كتب السفر، والكتب التي تركز على إتقان تعبيرات يتم مواجهتها بشكل متكرر في مواقف معينة ـوالذي يحتوي على المقرر الموقفي التالي:

\begin{tabular}{|c|c|c|}
\hline في المترل & في المطعم & في الطائرة \\
\hline عند الطبيد & في المقهى & ب الهجرة \\
\hline في المكتب & في الحانة & لبنك \\
\hline في السينما & في الحافلة & ي الهاتف \\
\hline في الفندق & في المتجر & الشارع \\
\hline في المطار & في مكتب البريد & \\
\hline
\end{tabular}

ومن إيجابيات المقررات الموقفية أها تقدم اللغة في سياق، وتدرس فيها اللغة لاستخدامها عمليا بشكل فوري. إن دور المواقف في تصميم المقررات دخل مرة أخرى إلى فئل تدريس اللغة حديثا، وإن كان بصيغة مختلفة عن المقررات الموقفية التقليدية، وذلك مع ظهور المذاهب الاتصالية في تصميم المقررات والإنجليزية لأغراض خاصة .

๑. المقرر الموضوعي أو الذي قوامه المختوى: Topical or content-based syllabus

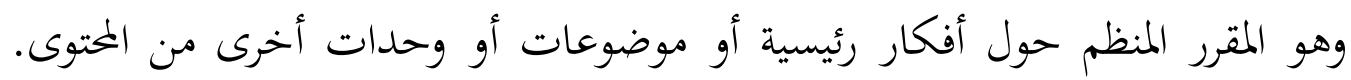

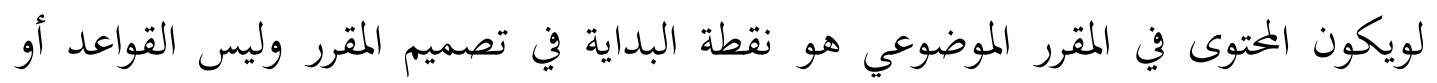

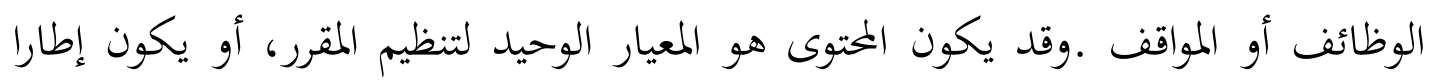

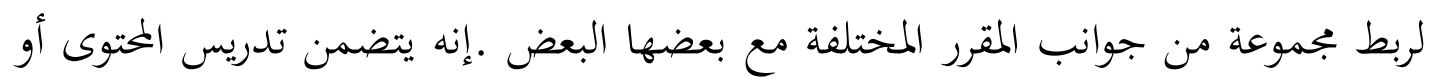
المعلومات من خلال اللغة المتعلمة مع جهل مباشر محدود لتدريس اللغة منفصلة عن المحتوى المدرس. ومن ثم يتم اختيار المحتوى ليظهر كيفية استخدام التركيب، وليقدم سياقا لممارسة ذلك التركيب .وبالمقابل ففي مقرر قوامه الموضوع، يوفر المحتوى الأداة لتقديم اللغة وليس العكس. 
ويستخدم المحتوى لأقصى درجة ليوفر الروابط والاستمرارية بين المهارات .وإيجابيات التدريس الذي يعتمد على المقررات التي قوامها المحتوى هي: (1) تسهل الفهم، (ب) يجعل المحتوى الصيغة اللغوية ذات معنى بشكل أكبر، (ب) يقدم المحتوى أساسا جيدا لتدريس المهارات ( ) تعالج حاجات الطلاب،(0) تزيد الدافعية عند المتعلمين، (7) تسمح بدمج المهارات الأربع، (V) تسمح باستخدام مواد تعليمية أصيلة. وقد تم استخدام هذا المذهب في برنامج في جامعة ألمانية، وقد وصفه Brinton وآخرون 919 أبأنه مبني حول الموضوعات التالية: ا ـ التلفاز العمارة الحلديثة ب. الإقناع الديني تقنية الرقائق الالكترونية

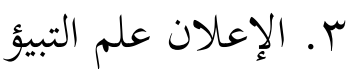
ع. الأدوية الطاقة البديلة هـ التمييز العنصري الطاقة النووية 7. الأمريكييون الأصليون الدراكولا في الأساطير والروايات والأفلام 7. المقرر الذي قوامه الكفايات: competency-based syllabus وهو مقرر يعتمد على تحديد الكفايات التي يتوقع من المتعلمين إتقاها فيما يتعلق بمواقف وأنشطة محددة. والكفايات هي وصف للمهارات والمعارف والتوجهات الأساسية المطلوبة للأداء الفعال لمهمات وأنشطة معينة .فمنهج مهارات العمل عند ( 191 ( ) Mrowicki كفايات منهج اللغة مقسمة إلى موضوعات وموضوعات بينية .ويشير الموضوع إلى السياق الذي تستخدم فيه اللغة ـومن الأمثلة على الكفايات المتعلقة بموضوع استخدام الهاتف" مايلي: أ. قراءة أرقام الماتف وإدارة قرص الهاتف. ب. ب-التعريف بالذات على الماتف عند الرد على الهاتف أو عند إجراء مكالمة. 
ت. ب-طلب التحدث مع شخص ما.

ث. ع -الرد على طلب الانتظار.

ج. م. - الرد على شخص يطلب تسجيل رسالة.

skills syllabus: مقرر المهارات: V

وهو مقرر منظم حول القدرات المختلفة الأساسية التي يتضمنها استخدام اللغة

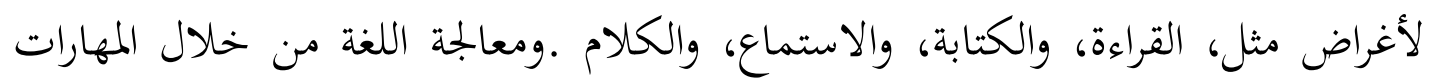

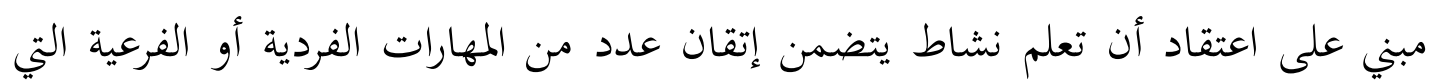

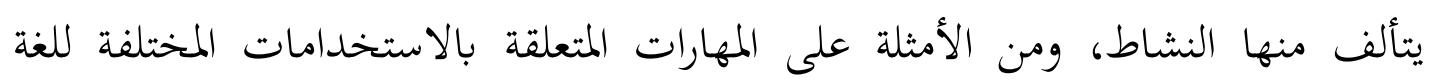

\begin{tabular}{|c|c|c|c|}
\hline الكتابة & القراءة & الكلام & الاستماع \\
\hline البئيسار الجملة اللموضوع & المقاءة من أجل & أخذ الدور على إشارات & المعلوف على المعات الأساسية \\
\hline 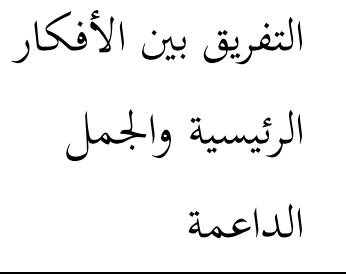 & تخمين معاني & تقديم موضوع & الدنطاب للتعرف واسمات على الخطاب \\
\hline التحرير الذاتي & باستدلالات القاء والقيام & إستخداتيجات الاتيات التصال & متابعة كلام سريع \\
\hline
\end{tabular}

م. المقرر الذي قوامه المهمة: Task-based syllabus

وهو مقرر منظم حول المهمات التي سوف ينجزها الطلاب في اللغة الهدف .والمهمة هي نشاط أو هدف ينفذ باستخدام اللغة مثل إيجاد حل لمعضلة، أو قراءة خريطة وإعطاء

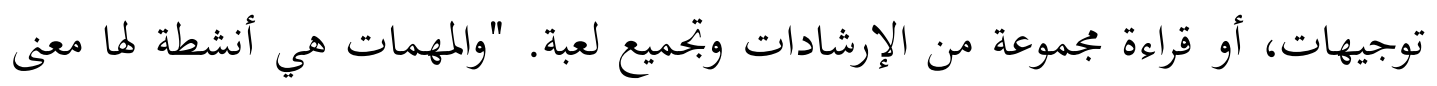


وهدف تركز عليهما وتدور حولما .ويتم تقويم النجاح في تنفيذ المهمات من خلال تحقيق نواتج محددة، كما أن المهمات بصورة عامة تتشابه مع استخدام اللغة في الواقع". تستخدم المهمات بأشكال مختلفة في كل أنواع التدريس، إلا أن المقرر الذي قوامه المهمة يعتمد على مهمات مصممة خصيصاً لتسهيل تعلم اللغة الثانية، إذ إن المهمات أو الأنشطة فيه تشكل الوحدات الأساسية في تصميم المقرر .ويقال إن المتعلمين عند القيام بهذه

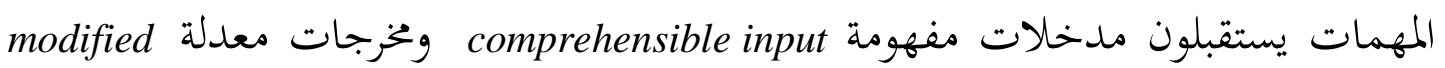
كoutput للمقرر الذي قوامه المهمة تتمثل فيما يلي: (1) المهمات هي أنشطة تقود عملية اكتساب لئل

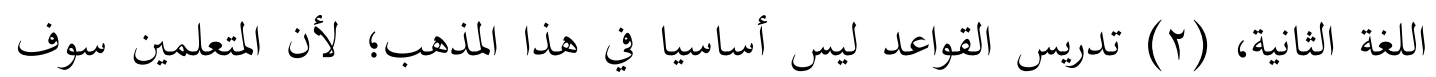
يكتسبون القواعد بطريقة، (r) غير مباشرة عند تنفيذ المهمات، (ع) تزيد المهمات دافعية المتعلمين وتجعلهم ينخرطون في اتصال هادف. 9. المقرر الذي قوامه النص: text-based syllabus وهو مقرر مبني على النصوص وعلى عينات من الخطاب المطول .ويمكن عد هذا النوع من المقررات نوعا من المذهب الموقفي لأن نقطة البداية في تخطيط المقرر هي تحليل السياقات التي سوف يستخدم فيها المتعلمون اللغة كما أشرنا إلى ذلك سابقا. يبدأ هذا المذهب بالنصوص التي حددت لسياق معين أو حددت بواسطة الطلاب .ويستخدم هذا

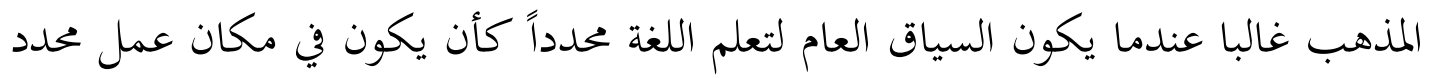

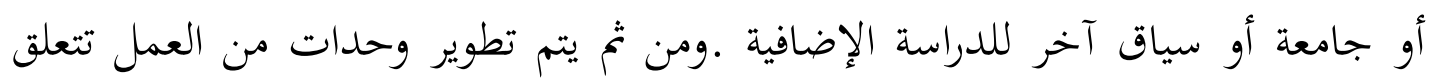

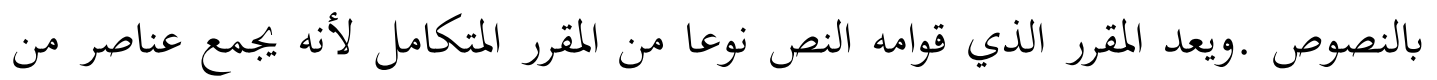

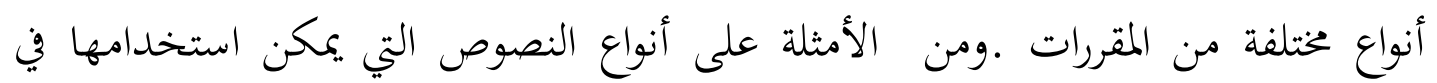
تخطيط مقرر قوامه النص ما يلي:

\begin{tabular}{|c|c|c|c|c|c|}
\hline نصوص إقناعية & نصوص قصصية & تحتوي على نصوص & إجراءات & صيغ & مبادلات \\
\hline
\end{tabular}




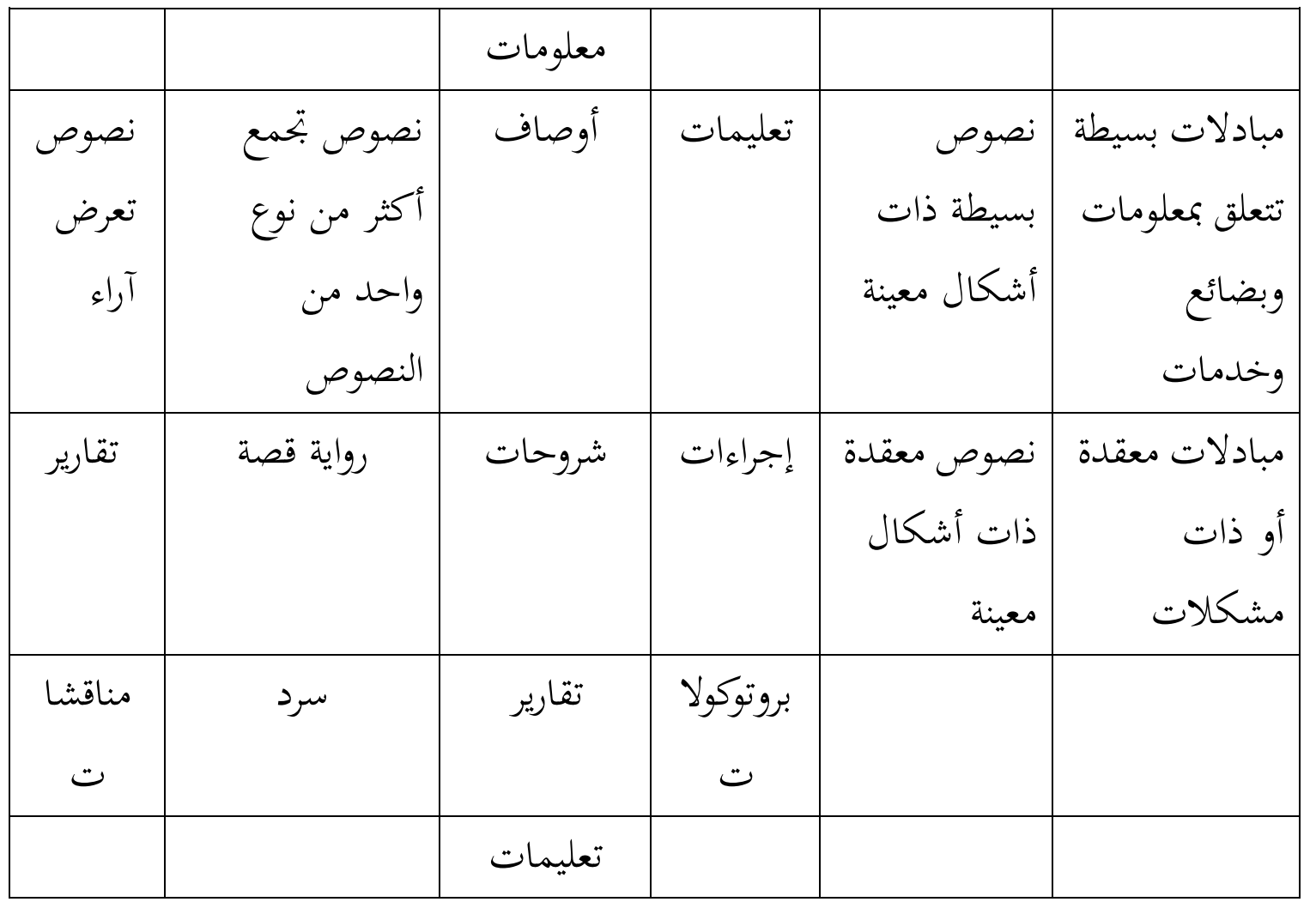

ع ـ مقرر متكامل: Integrated syllabus

القضية الجوهرية في اختيار إطار المقرر المناسب هي ما المبدأ الأساسي في تخطيط المقرر وما المبدأ الثانوي؟ فهناك بصورة عامة عدد من جوانب المقرر المختلفة في معظم إسمر

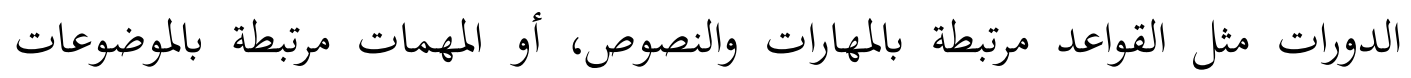
والوظائف، أو المهارات مرتبطة بالموضوعات والنصوص .ويحتاج مخططو الدورة- إذا أرادوا الوصول إلى قرار يتعلق بالمذهب الذي يجب تبنيه في تخطيط المقرر -إلى اتخاذ قرار يتعلق بالتمييز بين وحدات التخطيط ذات المستوى الأساسي وذات المستوى الفرعي في الدورة . ولذا فإن كل المقررات من الناحية العملية تعكس درجة معينة من الدمج أو التكامل . وينتهي إلى نتيجة مفادها من الواضح أن في كل البرامج التدريسية تقريبا حاجة للجمع بين أنواع مختلفة من

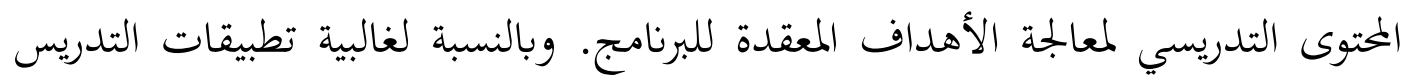
العامة والتي هَدف إلى تنمية القدرة الوظيفية في سياقات واسعة وتنمية المعرفة البنائية 
والقدرة الاتصالية في مواقف محددة، فالاختيار المرجح هو الجمع بين التدريس الوظيفي والبنائي والموقفي والمهاري .ومن ناحية أخرى، ففي بعض سياقات تدريس اللغة الثانية التي يمكن فيها تحديد المهارات والمهمات على نهو ضيق، والتي تكون فيها المصادر التدريسية أغنى، أو التي يكون فيها تحقيق معرفة بنائية أو رسمية محددة ليس ضروريا لنجاح الطلاب، يمكن الجمع بين تدريس قوامه المهمة وقوامه المهارة وتدريس موقفي ووظيفي وذي محتوى. رابعا: تقديم المقرر أ. مقرر تعليم الكلام في قسم تعليم اللغة العربية كلية التربية لمرحلة البكالوريوس بجامعة

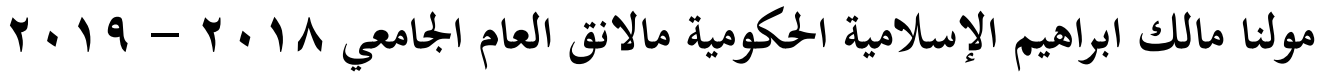
موضوع المادة : مهارة الكلام

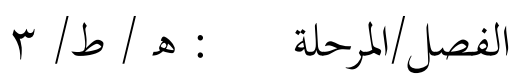

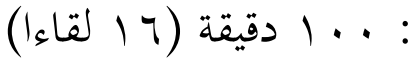

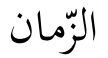

\begin{tabular}{|c|c|}
\hline حمكين الطلبة من الكفايات اللغوية والفنية في مهارة الكلام & الهدف العام \\
\hline 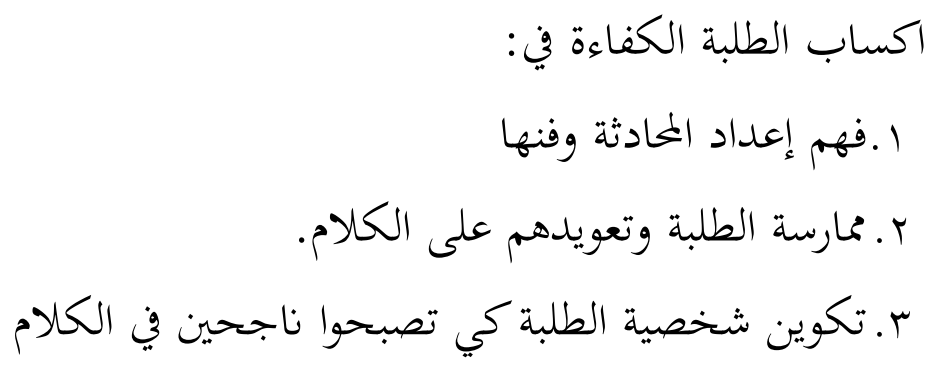 & الهدف الخاص \\
\hline 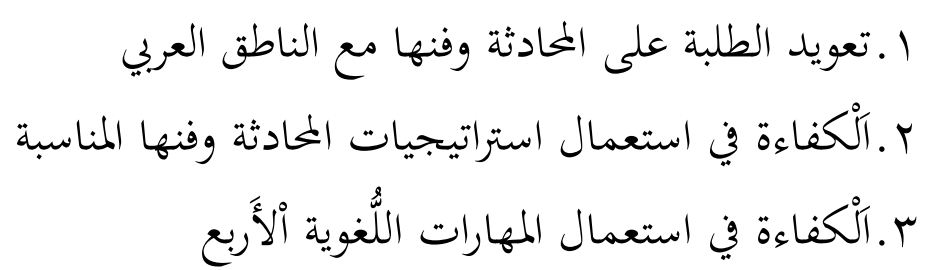 & آلْمؤشرات \\
\hline
\end{tabular}




\begin{tabular}{|c|c|}
\hline 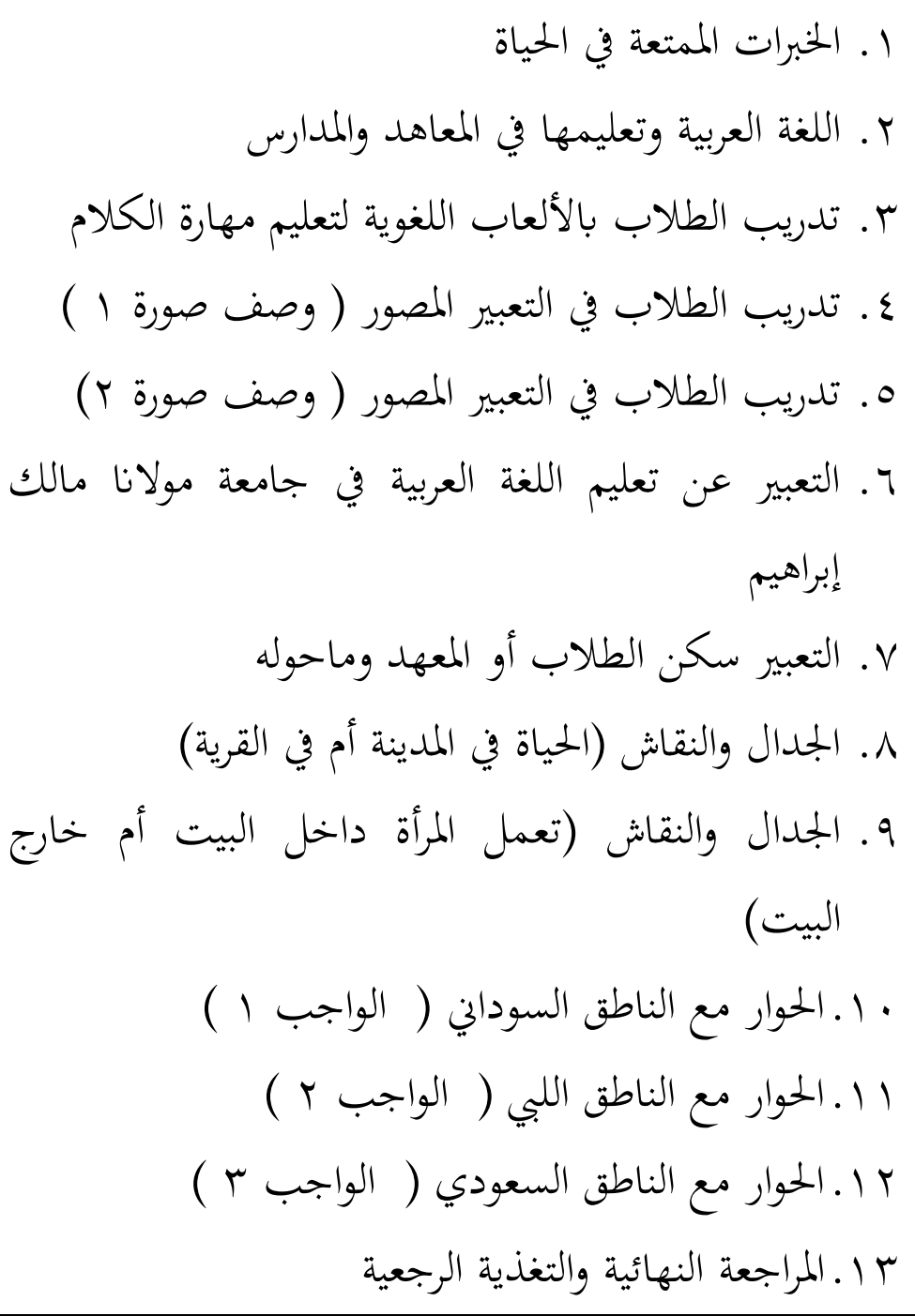 & الموضوعات أي المواد \\
\hline • المقدمة، والتحية، والثناء لله ولرسوله، ومحتويات المادة، & وصفية المواد \\
\hline 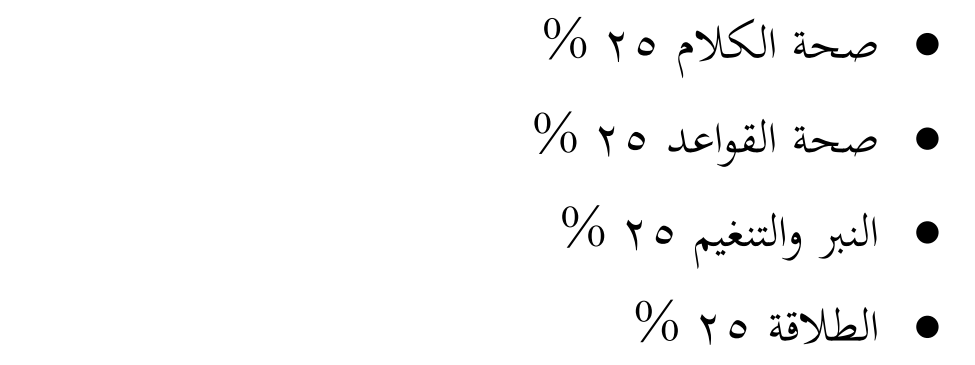 & التقويم في التطبيق \\
\hline 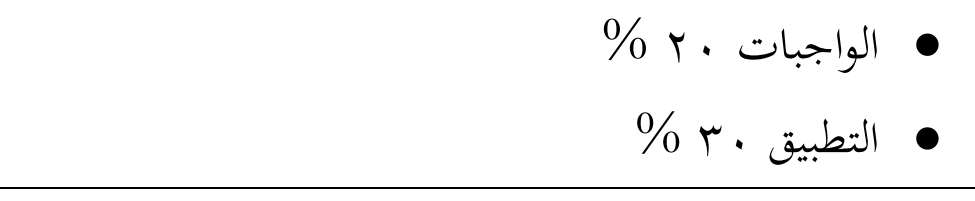 & التقويم \\
\hline
\end{tabular}




$$
\begin{aligned}
& \text { الاختبار النصفي •r \% } \\
& \text { الاختبار النهائي .r \% }
\end{aligned}
$$

ب. مقرر تعليم الكلام في قسم اللغة العربية وأدابها كلية العلوم والثقافة بجامعة مولنا مالك ابراهيم الإسلامية الحكومية مالانق 


\section{RENCANA PEMBELAJARAN SEMESTER}

MATA KULIAH

SKS

KODE

PROGRAM STUDI

SEMESTER

NAMA DOSEN PENGAMPU

COURSE LEARNING OUTCOMES

(Capaian Pembelajaran Mata Kuliah)
FAN AL KALAM

2 SKS

1431

BAHASA DAN SASTRA ARAB FAKULTAS HUMANIORA

II (DUA)

1. MEMAHAMI KONSEP UMUM TENTANG FAN AL KALAM ATAU PUBLIK SPEAKING

2. MEMAHAMI TEORI-TEORI FAN AL KALAM SERTA MAMPU MENGEKSPRESIKAN GAGASAN DALAM BENTUK LISAN.

3. MAMPU MENJADI PEMBACA ACARA YANG BAIK DAN BENAR.

\begin{tabular}{|c|c|c|c|c|c|c|c|}
\hline $\begin{array}{l}\text { Mingg } \\
\text { u Ke- }\end{array}$ & $\begin{array}{c}\text { Kemampuan yang } \\
\text { Diharapkan pada Setiap } \\
\text { Pertemuan }\end{array}$ & Bahan Kajian & $\begin{array}{c}\text { Metode } \\
\text { Pembelajar } \\
\text { an }\end{array}$ & $\begin{array}{l}\text { Waktu } \\
\text { Belajar } \\
\text { (Menit) }\end{array}$ & $\begin{array}{c}\text { Pengalaman Belajar } \\
\text { Mahasiswa } \\
\text { (Deskripsi Tugas) } \\
\end{array}$ & $\begin{array}{l}\text { Kriteria, Indikator dan } \\
\text { Bobot Penilaian }\end{array}$ & Daftar Referensi yang digunakan \\
\hline$(1)$ & $(2)$ & (3) & $(4)$ & $(5)$ & (6) & $(7)$ & (8) \\
\hline $\mathrm{Ke}-1$ & $\begin{array}{l}\text { Urgensi } \\
\text { mempelajari fan } \\
\text { al kalam }\end{array}$ & $\begin{array}{l}\text { 1- Menga } \\
\text { pa ada } \\
\text { mata } \\
\text { kuliah } \\
\text { Fan al } \\
\text { Kalam }\end{array}$ & & $\begin{array}{l}100 \\
\text { menit }\end{array}$ & $\begin{array}{l}\text { - Mengkaji urgensi MK } \\
\text { Fan al Kalam } \\
\text { - Memetakan } \\
\text { ketrampilan dalam } \\
\text { bahasa arab } \\
\text { - Mendiskusikan materi } \\
\text { yang akan diajarkan }\end{array}$ & $\begin{array}{l}\text { - Mampu memahami } \\
\text { gambaran umum } \\
\text { tentang materi yang } \\
\text { akan dipelajari. } \\
\text { - Mampu } \\
\text { menjelaskan } \\
\text { urgensi materi } \\
\text { untuk peningkatan } \\
\text { kompetensi } \\
\text { - Mampu } \\
\text { memberikan feed } \\
\text { back }\end{array}$ & 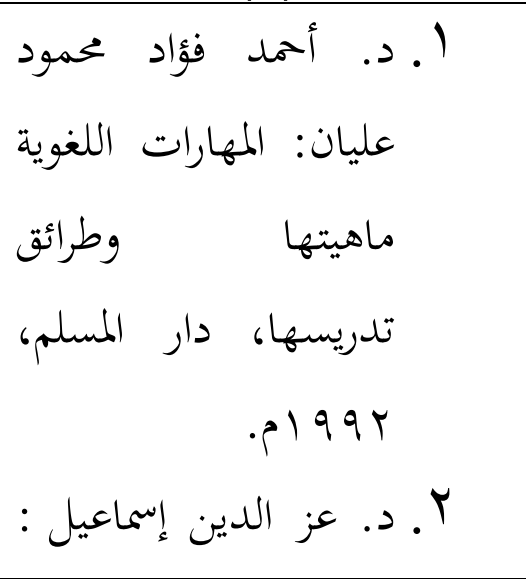 \\
\hline
\end{tabular}




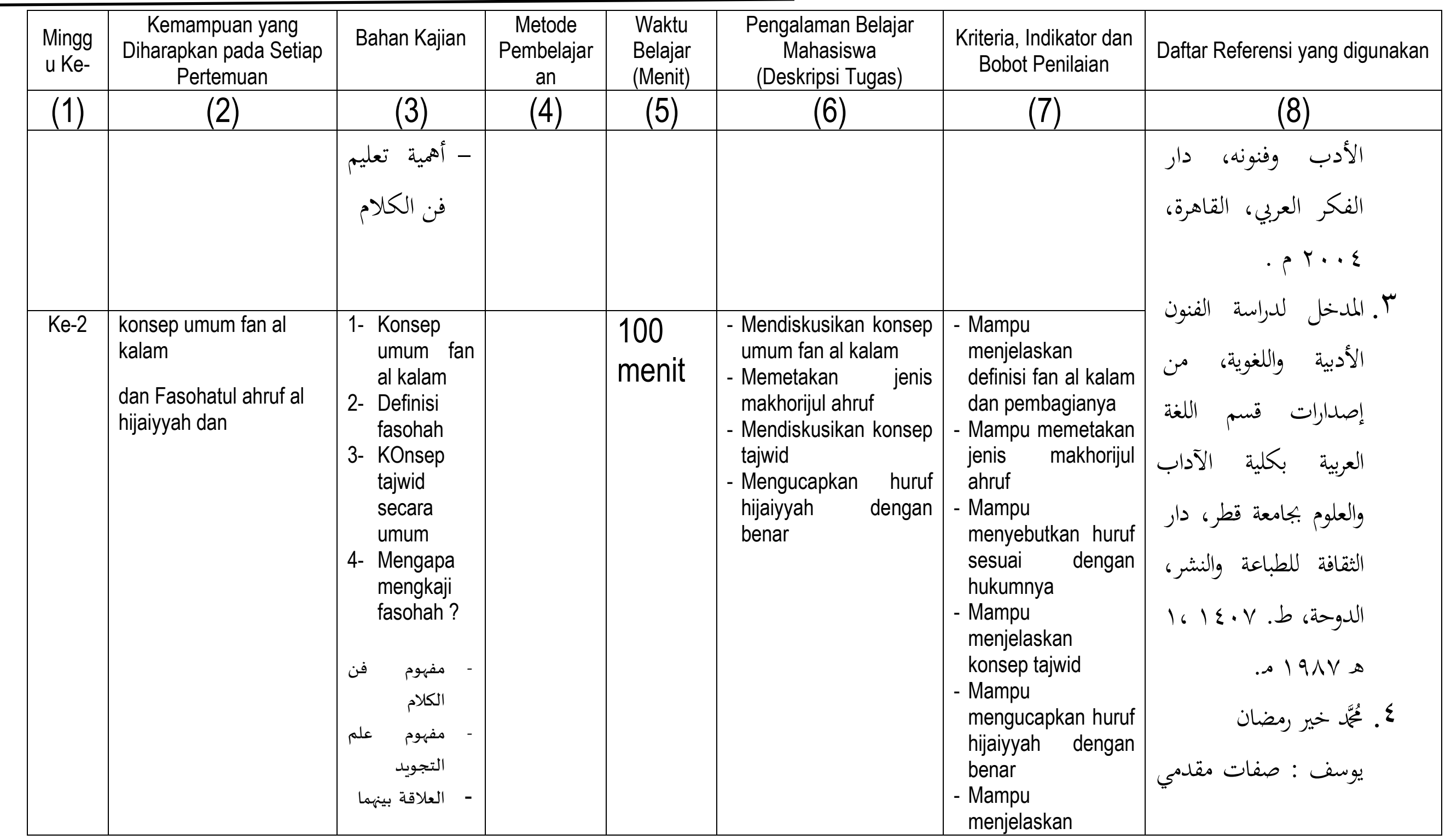




\begin{tabular}{|c|c|c|c|c|c|c|c|}
\hline $\begin{array}{l}\text { Mingg } \\
\text { u Ke- }\end{array}$ & $\begin{array}{c}\text { Kemampuan yang } \\
\text { Diharapkan pada Setiap } \\
\text { Pertemuan }\end{array}$ & Bahan Kajian & $\begin{array}{l}\text { Metode } \\
\text { Pembelajar } \\
\text { an }\end{array}$ & $\begin{array}{l}\text { Waktu } \\
\text { Belajar } \\
\text { (Menit) }\end{array}$ & $\begin{array}{c}\text { Pengalaman Belajar } \\
\text { Mahasiswa } \\
\text { (Deskripsi Tugas) }\end{array}$ & $\begin{array}{l}\text { Kriteria, Indikator dan } \\
\text { Bobot Penilaian }\end{array}$ & Daftar Referensi yang digunakan \\
\hline \multirow[t]{2}{*}{$(1)$} & $(2)$ & (3) & (4) & $(5)$ & (6) & $(7)$ & (8) \\
\hline & & & & & & $\begin{array}{l}\text { hubungan antara } \\
\text { ilmu tajwid dan MK } \\
\text { fan al kalam }\end{array}$ & البرامج الاسلامية ي \\
\hline Ke-3 & $\begin{array}{l}\text { Karakter seorang } \\
\text { pembawa acara }\end{array}$ & 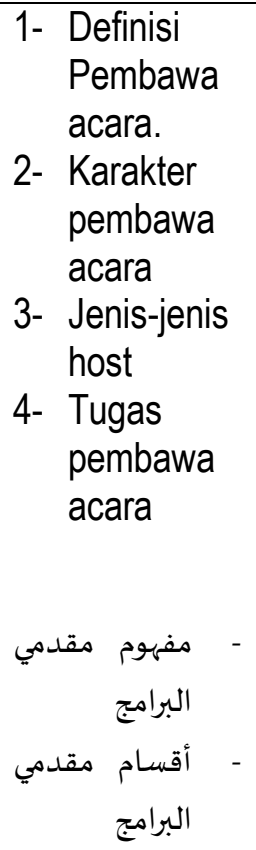 & & 100 menit & $\begin{array}{l}\text { - Mendengarkan } \\
\text { penjelasan dari dosen } \\
\text { - Mendiskusikan } \\
\text { karakter seorang } \\
\text { pembawa acara atau } \\
\text { host } \\
\text { - Mendiskusikan jenis- } \\
\text { jenis host } \\
\text { - Membuat ringkasan } \\
\text { tentang materi } \\
\text { - Mengerjakan tugas } \\
\text { yang telah diberikan }\end{array}$ & $\begin{array}{l}\text { - Mampu } \\
\text { menjelaskan } \\
\text { beberapa karakter } \\
\text { pembawa acara } \\
\text { atau host. } \\
\text { - Mampu } \\
\text { menjelaskan jenis- } \\
\text { jenis host } \\
\text { - Mampu membuat } \\
\text { ringkasan tentang } \\
\text { materi yang tekah } \\
\text { diajarkan } \\
\text { - Mampu } \\
\text { mengerjakan tugas } \\
\text { yang telah } \\
\text { diberikan }\end{array}$ & 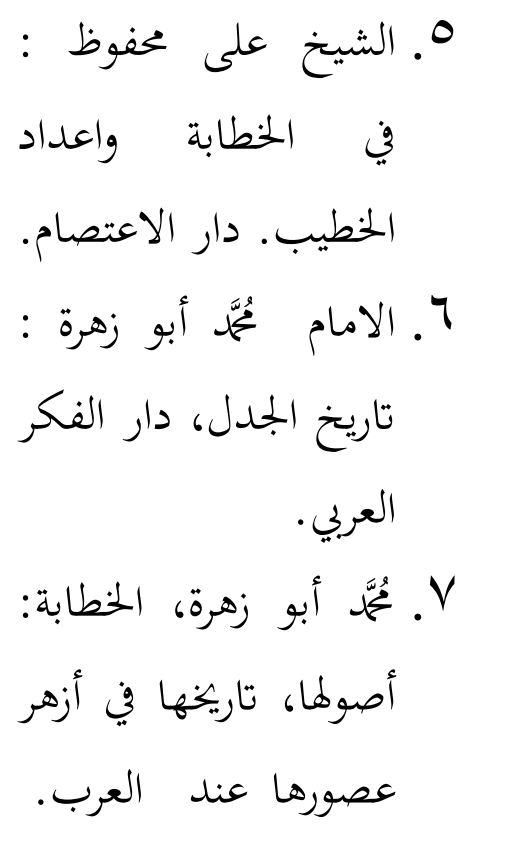 \\
\hline $\mathrm{Ke}-4$ & Teori menjadi MC & $\begin{array}{l}\text { 1- Definisi MC } \\
\text { 2- Tugas MC } \\
\text { 3- Jenis-jenis }\end{array}$ & & 100 menit & $\begin{array}{l}\text { - Mendengarkan } \\
\text { penjelasan dari dosen } \\
\text { - Mendiskusikan }\end{array}$ & $\begin{array}{l}\text { - Mampu } \\
\text { menjelaskan } \\
\text { beberapa karakter }\end{array}$ & \\
\hline
\end{tabular}




\begin{tabular}{|c|c|c|c|c|c|c|c|}
\hline $\begin{array}{l}\text { Mingg } \\
\text { u Ke- }\end{array}$ & $\begin{array}{c}\text { Kemampuan yang } \\
\text { Diharapkan pada Setiap } \\
\text { Pertemuan }\end{array}$ & Bahan Kajian & $\begin{array}{c}\text { Metode } \\
\text { Pembelajar } \\
\text { an }\end{array}$ & $\begin{array}{l}\text { Waktu } \\
\text { Belajar } \\
\text { (Menit) }\end{array}$ & $\begin{array}{c}\text { Pengalaman Belajar } \\
\text { Mahasiswa } \\
\text { (Deskripsi Tugas) }\end{array}$ & $\begin{array}{l}\text { Kriteria, Indikator dan } \\
\text { Bobot Penilaian }\end{array}$ & Daftar Referensi yang digunakan \\
\hline$(1)$ & $(2)$ & (3) & $(4)$ & $(5)$ & $(6)$ & (7) & (8) \\
\hline & & $\mathrm{MC}$ & & & $\begin{array}{l}\text { beberapa tugas MC } \\
\text { - karakter seorang MC } \\
\text { - Mendiskusikan jenis- } \\
\text { jenis host } \\
\text { - Membuat ringkasan } \\
\text { tentang materi } \\
\text { - Mengerjakan tugas } \\
\text { yang telah diberikan }\end{array}$ & $\begin{array}{l}\text { MC } \\
\text { - Mampu } \\
\text { menjelaskan jenis- } \\
\text { jenis host } \\
\text { - Mampu membuat } \\
\text { ringkasan tentang } \\
\text { materi yang tekah } \\
\text { diajarkan } \\
\text { - Mampu } \\
\text { mengerjakan tugas } \\
\text { yang telah } \\
\text { diberikan }\end{array}$ & \\
\hline Ke-5 & $\begin{array}{l}\text { Menjadi seorang } \\
\text { pembawa acara dan MC }\end{array}$ & $\begin{array}{l}\text { 1- Praktek } \\
\text { menjadi } \\
\text { seorang } \\
\text { pembawa } \\
\text { acara dan } \\
\text { MC } \\
\text { - البرامة لمقدمي } \\
\text { البرامج }\end{array}$ & & 100 menit & $\begin{array}{l}\text { - Mengaplikasikan } \\
\text { materi yang telah } \\
\text { diajarkan }\end{array}$ & $\begin{array}{l}\text { - Mampu } \\
\text { mengaplikasikan } \\
\text { materi yang telah } \\
\text { diajarkan }\end{array}$ & \\
\hline $\mathrm{Ke}-6$ & Pembawa acara d TV & 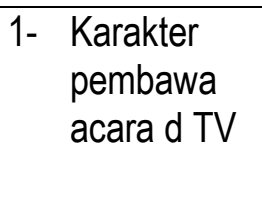 & & 100 menit & $\begin{array}{l}\text { - Memetakan jenis jenis } \\
\text { host } \\
\text { - Mendiskusikan } \\
\text { beberapa sifat }\end{array}$ & $\begin{array}{l}\text { - Mampu memetakan } \\
\text { jenis jenis host } \\
\text { - Mampu } \\
\text { menjelaskan }\end{array}$ & \\
\hline
\end{tabular}




\begin{tabular}{|c|c|c|c|c|c|c|c|}
\hline $\begin{array}{l}\text { Mingg } \\
\text { u Ke- }\end{array}$ & $\begin{array}{c}\text { Kemampuan yang } \\
\text { Diharapkan pada Setiap } \\
\text { Pertemuan }\end{array}$ & Bahan Kajian & $\begin{array}{c}\text { Metode } \\
\text { Pembelajar } \\
\text { an }\end{array}$ & $\begin{array}{l}\text { Waktu } \\
\text { Belajar } \\
\text { (Menit) }\end{array}$ & $\begin{array}{c}\text { Pengalaman Belajar } \\
\text { Mahasiswa } \\
\text { (Deskripsi Tugas) }\end{array}$ & $\begin{array}{l}\text { Kriteria, Indikator dan } \\
\text { Bobot Penilaian }\end{array}$ & Daftar Referensi yang digunakan \\
\hline$(1)$ & $(2)$ & $(3)$ & (4) & $(5)$ & $(6)$ & (7) & (8) \\
\hline & & & & & $\begin{array}{l}\text { pembaca berita } \\
\text { - Membuat ringkasan } \\
\text { materi yang telah } \\
\text { diajarkan } \\
\text { - Mengerjakan tugas }\end{array}$ & $\begin{array}{lr}\text { beberapa } & \text { sifat } \\
\text { pembawa acara di } \\
\text { TV } \\
\text { - Mampu membuat } \\
\text { ringkasan materi } \\
\text { yang } \\
\text { diajarkan } \\
\text { - Mampu } \\
\text { mengerjakan } \\
\text { yang tugas } \\
\text { diberikan }\end{array}$ & \\
\hline $\mathrm{Ke}-7$ & $\begin{array}{l}\text { Menjadi seorang } \\
\text { pembawa acara dan } \\
\text { Pembaca berita }\end{array}$ & 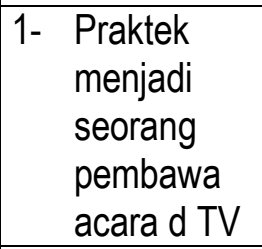 & & 100 menit & $\begin{array}{l}\text { - Mengaplikasikan } \\
\text { materi yang telah } \\
\text { diajarkan }\end{array}$ & $\begin{array}{l}\text { - Mampu } \\
\text { mengaplikasikan } \\
\text { materi yang telah } \\
\text { diajarkan }\end{array}$ & \\
\hline $\mathrm{Ke}-8$ & $\begin{array}{l}\text { UJI KOMPETENSI } \\
\text { MAHASISWA }\end{array}$ & U TS & - & - & - & - & \\
\hline $\mathrm{Ke}-9$ & $\begin{array}{l}\text { Ketrampilan } \\
\text { menyampaikan dan } \\
\text { mempresentasikan }\end{array}$ & $\begin{array}{l}\text { 1- Tips tips } \\
\text { sukses } \\
\text { membaca } \\
\text { berita } \\
\text { و التقديم } 1 \text { - } 1 \text { اراء }\end{array}$ & & 100 menit & $\begin{array}{l}\text { - Mendiskusikan materi } \\
\text { tentang teknik } \\
\text { menyampaikan. } \\
\text { - Membuat catatan kecil } \\
\text { tentang materi yang } \\
\text { telah diajarkan. } \\
\text { - Mengerjakan tugas. }\end{array}$ & $\begin{array}{l}\text { - Mampu } \\
\text { menjelaskan materi } \\
\text { tentang teknik } \\
\text { menyampaikan. } \\
\text { - Mampu } \\
\text { - Mampu } \\
\text { mengerjakan tugas }\end{array}$ & \\
\hline $\mathrm{Ke}-10$ & $\begin{array}{ll}\text { Aplikasi ketrampilan } \\
\text { menyampaikan dan }\end{array}$ & $\begin{array}{l}\text { 1- Praktek } \\
\text { menjadi }\end{array}$ & & 100 menit & $\begin{array}{l}\text { - Mengaplikasikan } \\
\text { materi yang telah }\end{array}$ & $\begin{array}{l}\text { - Mampu } \\
\text { mengaplikasikan }\end{array}$ & \\
\hline
\end{tabular}




\begin{tabular}{|c|c|c|c|c|c|c|c|}
\hline $\begin{array}{l}\text { Mingg } \\
\text { u Ke- }\end{array}$ & $\begin{array}{c}\text { Kemampuan yang } \\
\text { Diharapkan pada Setiap } \\
\text { Pertemuan }\end{array}$ & Bahan Kajian & $\begin{array}{c}\text { Metode } \\
\text { Pembelajar } \\
\text { an }\end{array}$ & $\begin{array}{l}\text { Waktu } \\
\text { Belajar } \\
\text { (Menit) }\end{array}$ & $\begin{array}{c}\text { Pengalaman Belajar } \\
\text { Mahasiswa } \\
\text { (Deskripsi Tugas) }\end{array}$ & $\begin{array}{l}\text { Kriteria, Indikator dan } \\
\text { Bobot Penilaian }\end{array}$ & Daftar Referensi yang digunakan \\
\hline$(1)$ & $(2)$ & (3) & (4) & $(5)$ & $(6)$ & $(7)$ & (8) \\
\hline & mempresentasikan & $\begin{array}{l}\text { pembaca } \\
\text { Berita }\end{array}$ & & & diajarkan & $\begin{array}{l}\text { materi yang telah } \\
\text { diajarkan }\end{array}$ & \\
\hline $\mathrm{Ke}-11$ & al Khitobah & 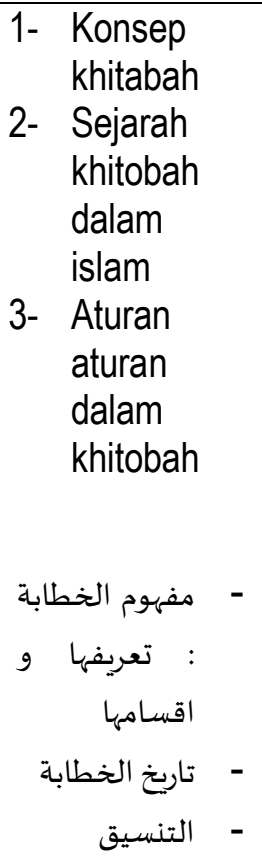 & & 100 menit & $\begin{array}{l}\text { - Mendengarkan } \\
\text { penjelasan dari dosen } \\
\text { - Mendiskusikan definisi } \\
\text { khitobah } \\
\text { - Membuat rangkuman } \\
\text { tentang sejarah } \\
\text { khitobah } \\
\text { - Mengerjakan tugas }\end{array}$ & $\begin{array}{l}\text { - Mampu } \\
\text { menjelaskan } \\
\text { definisi khitobah } \\
\text { - Mampu mengetahui } \\
\text { sejarah khitobah } \\
\text { dalam islam } \\
\text { - Mampu menjelskan } \\
\text { aturan aturan } \\
\text { dalam khitobah } \\
\text { - Mampu jenis } \\
\text { menjelaskan adabul } \\
\text { khitobah } \\
\text { - Mampu } \\
\text { menjelaskan jenis } \\
\text { jenis khitobah } \\
\text { - Mampu } \\
\text { mengerjakan tugas }\end{array}$ & \\
\hline $\mathrm{Ke}-12$ & Aplikasi al khitobah & $\begin{array}{l}\text { Praktek } \\
\text { khitobah }\end{array}$ & & 100 menit & $\begin{array}{l}\text { - Mengaplikasikan } \\
\text { materi yang telah } \\
\text { diajarkan }\end{array}$ & $\begin{array}{l}\text { - Mampu } \\
\text { mengaplikasikan } \\
\text { materi yang telah } \\
\text { diajarkan }\end{array}$ & \\
\hline $\mathrm{Ke}-13$ & al Jidal & $\begin{array}{l}\text { 1- Konsep al } \\
\text { jidal } \\
\text { 2- Perbedaan }\end{array}$ & & 100 menit & $\begin{array}{l}\text { - Mendengarkan } \\
\text { penjelasan dari dosen } \\
\text { - Mendiskusikan definisi }\end{array}$ & $\begin{array}{l}\text { - Mampu } \\
\text { menjelaskan } \\
\text { definisi al jidal }\end{array}$ & \\
\hline
\end{tabular}




\begin{tabular}{|c|c|c|c|c|c|c|c|}
\hline $\begin{array}{l}\text { Mingg } \\
\text { u Ke- }\end{array}$ & $\begin{array}{c}\text { Kemampuan yang } \\
\text { Diharapkan pada Setiap } \\
\text { Pertemuan }\end{array}$ & Bahan Kajian & $\begin{array}{c}\text { Metode } \\
\text { Pembelajar } \\
\text { an }\end{array}$ & $\begin{array}{l}\text { Waktu } \\
\text { Belajar } \\
\text { (Menit) }\end{array}$ & $\begin{array}{c}\text { Pengalaman Belajar } \\
\text { Mahasiswa } \\
\text { (Deskripsi Tugas) }\end{array}$ & $\begin{array}{l}\text { Kriteria, Indikator dan } \\
\text { Bobot Penilaian }\end{array}$ & Daftar Referensi yang digunakan \\
\hline$(1)$ & $(2)$ & (3) & (4) & $(5)$ & (6) & $(7)$ & (8) \\
\hline & & 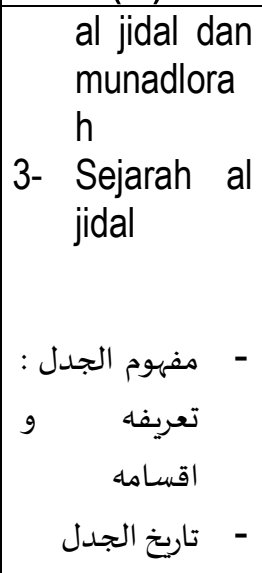 & & & $\begin{array}{l}\text { al jidal } \\
\text { - Membuat rangkuman } \\
\text { tentang sejarah al jidal } \\
\text { - Mengerjakan tugas }\end{array}$ & $\begin{array}{l}\text { - Mampu mengetahui } \\
\text { sejarah al jidal } \\
\text { dalam islam } \\
\text { - Mampu menjelskan } \\
\text { aturan aturan } \\
\text { dalam al jidal } \\
\text { - Mampu } \\
\text { menjelaskan adabul } \\
\text { jidal } \\
\text { - Mampu } \\
\text { mengerjakan tugas }\end{array}$ & \\
\hline Ke-14 & Aplikasi al jidal & Praktek al jidal & & 100 menit & $\begin{array}{l}\text { - Mengaplikasikan } \\
\text { materi yang telah } \\
\text { diajarkan }\end{array}$ & $\begin{array}{l}\text { - Mampu } \\
\text { mengaplikasikan } \\
\text { materi yang telah } \\
\text { diajarkan }\end{array}$ & \\
\hline Ke-15 & Al Taqwim atau evaluasi & 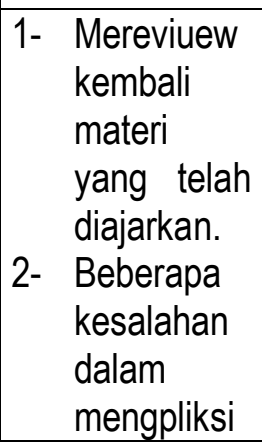 & & 100 menit & $\begin{array}{l}\text { - Mendengarkan } \\
\text { penjelasan dari dosen } \\
\text { - Memetakan kesalahan } \\
\text { mahasiswa dalam } \\
\text { mengaplikasikan teori } \\
\text { fan al kalam }\end{array}$ & $\begin{array}{l}\text { - Mampu mentashih } \\
\text { beberapa } \\
\text { kesalahan yang } \\
\text { telah dilakukan } \\
\text { dalam aplikasi teori } \\
\text { fan al kalam. } \\
\text { - Mampu } \\
\text { menjelaskan } \\
\text { beberapa }\end{array}$ & \\
\hline
\end{tabular}




\begin{tabular}{|c|c|c|c|c|c|c|c|}
\hline $\begin{array}{l}\text { Mingg } \\
\text { u Ke- }\end{array}$ & $\begin{array}{c}\text { Kemampuan yang } \\
\text { Diharapkan pada Setiap } \\
\text { Pertemuan }\end{array}$ & Bahan Kajian & $\begin{array}{c}\text { Metode } \\
\text { Pembelajar } \\
\text { an }\end{array}$ & $\begin{array}{l}\text { Waktu } \\
\text { Belajar } \\
\text { (Menit) }\end{array}$ & $\begin{array}{c}\text { Pengalaman Belajar } \\
\text { Mahasiswa } \\
\text { (Deskripsi Tugas) }\end{array}$ & $\begin{array}{l}\text { Kriteria, Indikator dan } \\
\text { Bobot Penilaian }\end{array}$ & Daftar Referensi yang digunakan \\
\hline$(1)$ & $(2)$ & $(3)$ & (4) & $(5)$ & $(6)$ & $(7)$ & (8) \\
\hline & & $\begin{array}{l}\text { kan meteri } \\
\text { fan al } \\
\text { kalam }\end{array}$ & & & & $\begin{array}{l}\text { kesalahan dalam } \\
\text { mengaplikasikan } \\
\text { teori fan al kalam }\end{array}$ & \\
\hline $\mathrm{Ke}-16$ & $\begin{array}{l}\text { UJI KOMPETENSI } \\
\text { MAHASISWA }\end{array}$ & - & - & - & - & - & - \\
\hline
\end{tabular}


سادسا: دراسة تقويمية عن المقرر في تعليم الكلام في قسم تعليم اللغة العربية كلية

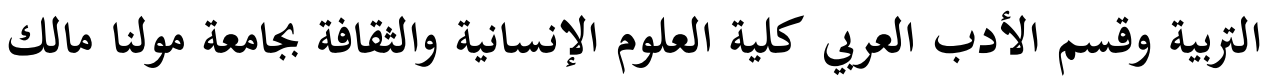
ابراهيم الإسلامية الحكومية مالانق أ. مقرر تعليم الكلام في قسم تعليم اللغة العربية كلية التربية بجامعة مولنا مالك ابراهيم الإسلامية الحكومية مالانق

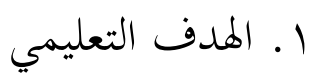

كان المدف العام من مهارة الكلام في قسم تعليم اللغة العربية العامة هو تمكين الطلبة من الكفايات اللغوية والفنية في مهارة الكلام حول

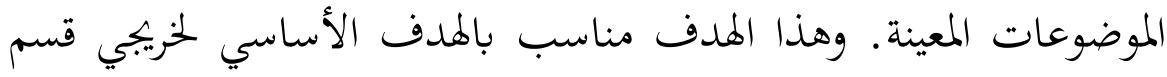
تعليم اللغة العربية الذي له الشروط الأساسية لأهلية المعلم وهي توافر الأسيات

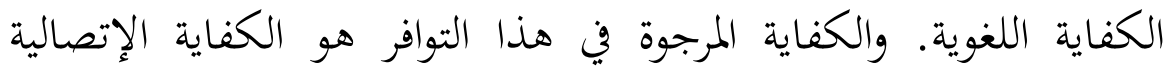

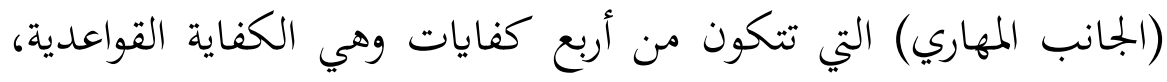

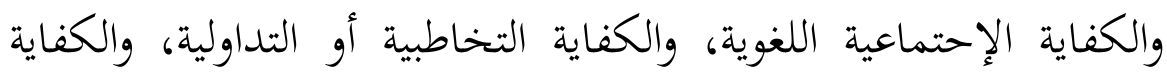

$$
\text { الإستراتيجية. }
$$

$$
\text { r. تصوير المواد الدراسية }
$$

إن مهارة الكلام في هذا القسم تقدم في المرحلة الثالثة. وهذه المادة من المناء

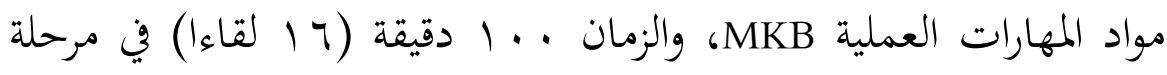

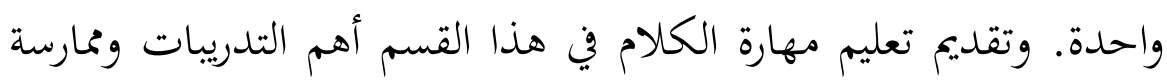
الطلبة وتعويدهم على الككام في التكلم ببداية كتابة النصوص قبل التطبيق

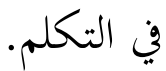




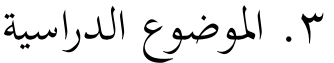

- أنواع تقديم تعليم الموضوع الدراسية تجري على مايلي: كتدريب الطلاب الطباب

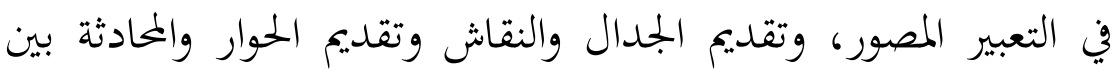

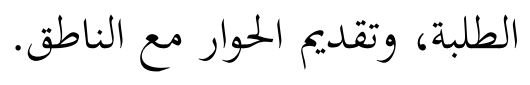

- الطريقة التعليمية تمشي حسب الواقعية في الفصل وكذلك على حسب الفي

قدر عقول وذهن الطلبة والطريقة تتغير حسب المواد المناسبة والحال

$$
\text { الواقعية. }
$$

- العمليات تتنوع على عمل منزلي وعمل بيتي، وهذا العمل تتكون من

التدريبات ومع ذلك الحوار والقصة و كتابة النصوص قبل التطبيق في

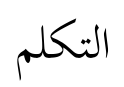

$$
\text { ع. التقويم }
$$

- نجاح الطلاب في دراستهم تتعلق كثيرا على حضورهم عند الدراسة وفعاليتهم عند الدراسة.

- نجاح الطلاب في تطبيق مهارة الكلام بصحة الكلام، وصحة القواعد، والنبر والتنغيم، والطلاقة

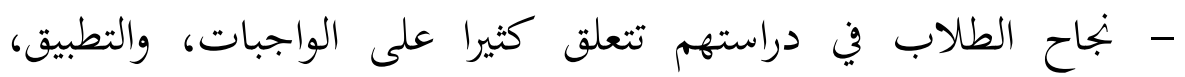

$$
\text { والاختبار النصفي، والاختبار النهائي }
$$

ب.مقرر تعليم الكلام في قسم الأدب العريي كلية العلوم الإنسانية والثقافة بجامعة مولنا مالك ابراهيم الإسلامية الحكومية مالانق

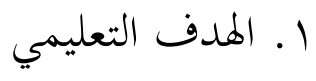

كان الهدف من تعليم فن الكلام في هذا القسم هو تمكين الطلبة من الكفايات اللغوية والفنية حول الموضوعات المعينة بتصحيح النبر والتنغيم والصوت المناسبة بنظام النحو وثقافة عربية. وهذا الهدف مناسب بالهدف 
الأساسي لخرييجي قسم اللغة العربية وأدابها الذي له الشروط الأساسية وهي

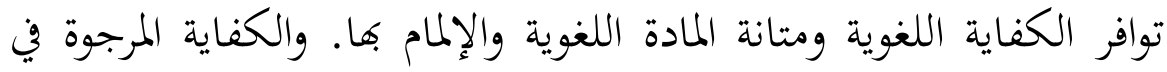
هذا التوافر هو الكفاية الإتصالية (الجانب المهاري) والكفاية المعرفية

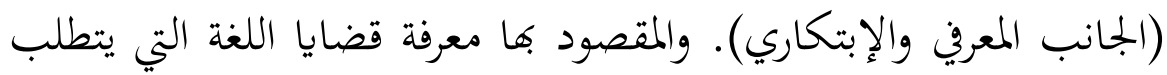
تدريسها معرفة عملية دقيقة، تناسب الزمن الذي نعيش فيه لتكون للمعلم القدرة على أن يؤسس ثقة قلوب الطلبة بمادته، ولا يقتصر الأمر على

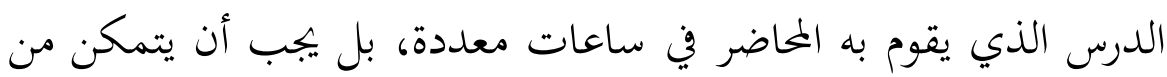
المادة التي يقوم بتدريسها وكيف تتصل تلك المادة بالمواد الأخرى وبالحياة

$$
\text { r. تصوير المواد الدراسية }
$$

إن تعليم فن الكلام في هذا القسم تقدم في المرحلة الثالثة. وهذه المادة من

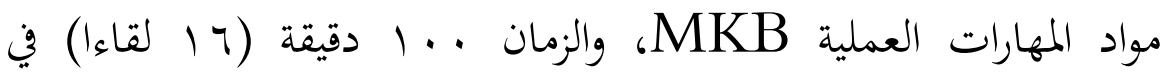
مرحلة واحدة. وتقديم تعليم فن الكلام في هذا القسم أهم النظريات والتدريبات ونقصان ممارسة الطلبة وتعويدهم على الكلام.

$$
\text { r. - م. الموضوع الدراسية }
$$

- تقديم التعليم بإلقاء نظريات عن المواد المعينة وإدخال تعليم التجويد

$$
\text { وبخارج الحروف }
$$

- أنواع تقديم تعليم الموضوع الدراسية تجري على مايلي: كتقديم النظريات عن المواد المعينة، وتدريب الطلاب في مقدمي البرامج، وتقديم الجدال. - عدم الطريقة التعليمية المكتوبة في خطة الدراسية - العمليات تتنوع على عمل منزلي، وهذا العمل يتكون من إيضاح

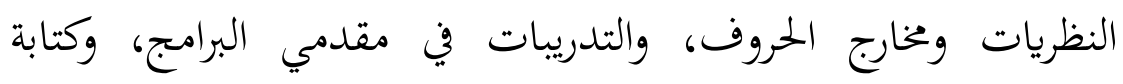
النصوص قبل التطبيق في التكلم. 


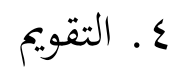

- نقصان المحاضر في إعطاء عملية تطبيق مهارة الكلام للطلبة. - نجاح الطالاب في دراستهم تتعلق كثيرا على حضورهم عند الدراسة

$$
\text { وفعاليتهم عند الدراسة. }
$$

- نجاح الطلاب في تطبيق فن الكالام بصحة خخارج الحروف والتجويد، وصحة القواعد، والنبر والتنغيم، والطلاقة

- نجاح الطلاب في دراستهم تتعلق كثيرا على الواجبات، والتطبيق،

$$
\text { والاختبار النصفي، والاختبار النهائي }
$$

\section{الحملاصة}

الاختنام

1. المقرر هو تحديد محتوى التدريس، وهو يرصد ما سوف يتم تدريسه ويجري الإختبار عليه. ومن هنا فإن مقرر التدريس في مهارة الكلام يحدد أنواع المهارات الشفهية التي سوف يتم تدريسها وممارستها خلال التدريس، وكذلك الوظائف أو الموضوعات أو جوانب المحادثة الأخرى التي سوف تدرس، والترتيب الذي سوف تظهر عليه في التدريس.

Y. أن مقرر تعليم مهارة الكالام في قسم تعليم اللغة العربية كلية التربية بجامعة مولنا مالك ابراهيم الإسلامية الحلكومية مالانق هو تمكين الطلبة من الكفايات اللغوية،

$$
\text { والكفاية المرجوة في هذا القسم هي الكفاية الإتصالية (الجانب المهاري) }
$$

ب. ومقرر تعليم الكالام في قسم الأدب العربي كلية العلوم الإنسانية والثقافة بجامعة مولنا مالك ابراهيم الإسلامية الحكومية مالانق هو تمكين الطلبة من الكفايات 
اللغوية والفنية حول الموضوعات المعينة بتصحيح النبر والتنغيم والصوت المناسبة بنظام النحو وثقافة عربية. والكفاية المرجوة في هذا القسم هي التوافر هو الكفاية الإتصالية (الجانب المهاري) والكفاية المعرفية (الجانب المعري والإبتكاري).

\section{قائمة المراجع}

أحمد فؤاد محمود عليان، ب 199 هـ، المهارات اللغوية واهميتها و طرائق تدريسها، الرياض: دار المسلم للنشر و التوزيع

إبراهيم مدكور، 910 1، المعجم الوسييط، الجزء الثاني، مصر: بجمع اللغة العربية

جاك ريتشاردز، بدون السنة، تطوير مناهج تعليم اللغة العببية Curriculum Development in Language Teaching ناصر الشويرخ

رشدي أحمد طعيمة، 919 1، تعليم اللغة العربية لغير الناطقين بها: مناهجه وأساليبه، الرباط: إيسسكو

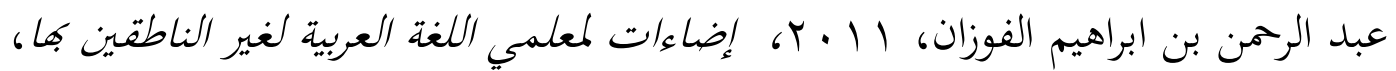

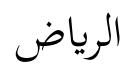

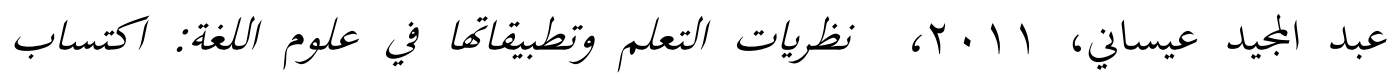

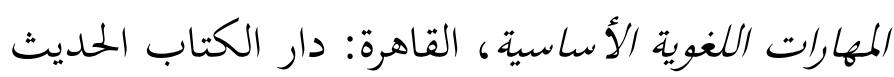

تُحَّمَ السيد على، مصطلحات في المناهج وطرق التدربس، المنصورة عامر للطباعة والنشر، 1911 


$$
\begin{aligned}
& \text { محمود كامل الناقة و رشدي أحمد طعيمة ، ب . . ب، طرائق تلديس اللغة العربية لغير } \\
& \text { الناطقين بها، ط. (1، منشورات المنظمة الإسالامية للتربية والعلوم والثقافة-إيسيسكو } \\
& \text { جموعة باحثين، اللغة العربية في إنلدونيسيا، الرياض: دار وجوه للنشر والتوزيع، } 10 \\
& \text { محلوءة الحسنة، · 1 • ب6 واقع تعليم للغة العببية في الجامعات الإنلونيسية، مجموعة } \\
& \text { باحثين في كتاب اللغة العربية في إندونيسيا، الرياض: دار وجوه للنشر والتوزيع } \\
& \text { منى إبراهيم اللبودى, ب . . Y، الحوار: فنياته و استراتيجياته وأساليب تعليميه, القاهرة: } \\
& \text { مكتبة وهبة } \\
& \text { نصر الدين ادريس جوهر، التجاهات جلديلة في مجال تعليم اللغة العببية في إندونيسيا، } \\
& 2017 \text { Journal Of Indonesian Islam Vol.01 Number } 01
\end{aligned}
$$

E Mulyasa, Kurikulum Tingkat Satuan Pendidikan: Suatu Panduan Praktis, Bandung: Remaja Rosdakarya, 2007

Ella Yulaelawati, Kurikulum dan Pembelajaran: Filosofi Teori dan Aplikasi, Bandung: Pakar Raya, 2004

Erfan Soebahar, "Membuat Silabus dan rencana Pembelajaran Semester-Prof. DR. H.M.Erfan Soebahar," accessed Okober 16, 2018, http://erfansoebahar.web.id/membuat-silabus-dan-rencana-pembelajaransemester/. 